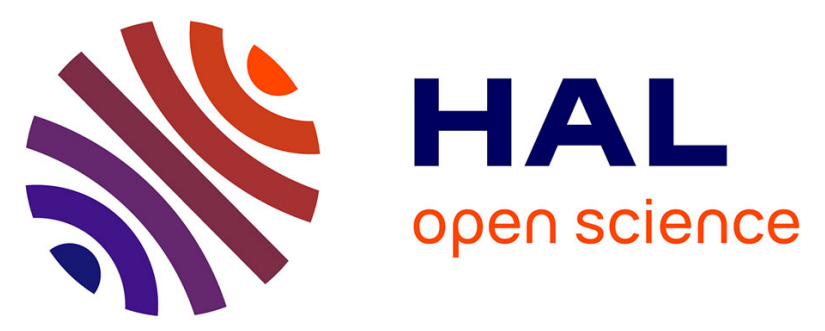

\title{
Chimeric Protein-Protein Interface Inhibitors Allow Efficient Inhibition of Type III Secretion Machinery and Pseudomonas aeruginosa Virulence
}

Tuan-Dung Ngo, Sophie Plé, Aline Thomas, Caroline Barette, Antoine Fortuné, Younes Bouzidi, Marie-Odile Fauvarque, Rossimiriam Pereira de Freitas, Flaviane Francisco Hilário, Ina Attree, et al.

\section{To cite this version:}

Tuan-Dung Ngo, Sophie Plé, Aline Thomas, Caroline Barette, Antoine Fortuné, et al.. Chimeric Protein-Protein Interface Inhibitors Allow Efficient Inhibition of Type III Secretion Machinery and Pseudomonas aeruginosa Virulence. ACS Infectious Diseases, 2019, 5 (11), pp.1843-1854. 10.1021/acsinfecdis.9b00154 . hal-02318760

\author{
HAL Id: hal-02318760 \\ https://hal.science/hal-02318760
}

Submitted on 23 Dec 2020

HAL is a multi-disciplinary open access archive for the deposit and dissemination of scientific research documents, whether they are published or not. The documents may come from teaching and research institutions in France or abroad, or from public or private research centers.
L'archive ouverte pluridisciplinaire HAL, est destinée au dépôt et à la diffusion de documents scientifiques de niveau recherche, publiés ou non, émanant des établissements d'enseignement et de recherche français ou étrangers, des laboratoires publics ou privés. 


\section{Chimeric protein-protein interface inhibitors allow efficient inhibition of Type III secretion machinery and Pseudomonas aeruginosa virulence}

Tuan-Dung Ngo, ${ }^{\ddagger}$ Sophie Plé,${ }^{\dagger}$, Aline Thomas, ${ }^{\dagger}$ Caroline Barette, ${ }^{\S}$ Antoine Fortuné, ${ }^{\dagger}$ Younes Bouzidi, ${ }^{\dagger}$ Marie-Odile Fauvarque, ${ }^{\S}$ Rossimiriam Pereira de Freitas, ${ }^{*}$ Flaviane Francisco Hilário, ${ }^{\perp}$ Ina Attrée, ${ }^{\ddagger}$ Yung-Sing Wong, ${ }^{* \dagger}$ and Eric Faudry* ${ }^{*}$

${ }^{\dagger}$ Univ. Grenoble Alpes, CNRS, Département de Pharmacochimie Moléculaire, UMR 5063, ICMG FR 2607, 470 rue de la chimie, 38000, Grenoble, France. yung-sing.wong@univ-grenoble-alpes.fr

\$ Univ. Grenoble Alpes, CEA, INSERM, CNRS, Bacterial Pathogenesis and Cellular Responses, UMR 1036/ERL 5261, 17 avenue des Martyrs, 38054, Grenoble, France. eric.faudry@ cea.fr

${ }^{\S}$ Univ. Grenoble Alpes, CEA, Inserm, IRIG, BGE, Genetics \& Chemogenomics, 17 avenue des Martyrs, 38054, Grenoble, France

* Universidade Federal de Minas Gerais, Depertamento de Química, UFMG, Av Pres Antônio Carlos, 6627, Pampulha, Belo Horizonte, MG 31270-901, Brazil

${ }^{\perp}$ Universidade Federal de Ouro Preto, Departamento de Química, ICEB, Campus Universitário Morro do Cruzeiro, 35400-000 Ouro Preto, Minas Gerais Brazil

Pseudomonas aeruginosa is an opportunistic pathogen naturally resistant to many common antibiotics that acquires new resistance traits at an alarming pace. Targeting the bacterial virulence factors by an anti-virulence strategy therefore represents a promising alternative approach besides antibiotic therapy. The Type III Secretion System (T3SS) of $P$. aeruginosa is one of its main virulence factors. It consists of more than 20 proteins building a complex syringe-like machinery enabling the injection of toxin into host cells. Previous works showed that disrupting interactions between components of this machinery efficiently lowers the bacterial virulence. Using automated target-based screening of commercial and in-house libraries of small molecules, we identified compounds inhibiting the protein-protein interaction between PscE and PscG, the two cognate chaperones of the needle subunit PscF of $P$. aeruginosa T3SS. Two hits were selected and assembled using Split/Mix/Click chemistry to build larger hybrid analogues. Their efficacy and toxicity were evaluated using phenotypic analysis including automated microscopy and image analysis. Two nontoxic hybrid leads specifically inhibited the T3SS and reduced the ex vivo cytotoxicity of bacteria and their virulence in Galleria mellonella. Keywords: Type III Secretion System, Antivirulence, bacteria resistance, protein-protein interface inhibitors, hybrid molecules, Click chemistry

The World Health Organization recently published a list of antibiotic-resistant pathogenic bacteria for which the search for new treatments is a high priority. ${ }^{1}$ This list includes the Gram-negative bacterium Pseudomonas aeruginosa, known for its intrinsic and acquired resistance to antibiotics and its capacity to form biofilms and to adapt to different environments. It represents a serious public health problem in terms of nosocomial infection and is the first cause of mortality in ventilator associated pneumonia and burn infections. ${ }^{2,3}$ In addition, this pathogen is responsible for severe chronic infections, especially in people with cystic fibrosis. 4

Faced with the adaptation of this bacterium to antibacterial treatments, it is urgent to develop other therapeutic approaches that do not rely solely on bactericidal or bacteriostatic activities. ${ }^{5,6}$ An emerging alternative approach is based on the inhibition of bacterial virulence to reduce its pathogenic character without affecting its integrity, so as to reduce the selection of resistance to treatments. ${ }^{7}$ In this perspective small molecules have been shown effective in targeting pathogen-specific virulence factors. ${ }^{8}$

$P$. aeruginosa pathogenicity strongly relies on its Type III Secretion System (T3SS), a conserved virulence trait among Gram-negative bacteria. ${ }^{9}$ This complex protein machinery allows the direct injection of toxins into the eukaryotic target cells. It is composed of three main structural parts: i) the basal body is embeded in the two bacterial membranes and protrudes 
toward the cytoplasm; ii) the needle connects the bacterium to the target cell and iii) the translocon forms a pore in the host cytoplasmic membrane and is linked to the needle by the tip protein (Figure 1a).

The use of therapeutic antibodies that target the translocon via the recognition of the PcrV tip protein demonstrated the effectiveness of anti-T3SS approach in murine infection models. ${ }^{10}$ Small molecules were also identified as inhibitors of bacterial virulence mainly thanks to high-throughput phenotypic screening campaigns. However, the exact mechanism of action of these small molecules remains to be correlated to T3SS inhibition. ${ }^{1-16}$ Very recently, a family of natural compounds was described to prevent the binding of PscF to its co-chaperones complex PscE-PscG. ${ }^{17}$

In the bacterial cytoplasm, the premature polymerization of the needle subunit $\mathrm{PscF}$ is prevented by its association to two co-chaperones, PscE and PscG. ${ }^{18}$ The crystallographic structure of the heterotrimeric complex ${ }^{19}$ revealed that the $\mathrm{PscF}$ amphipathic helix involved in the needle polymerization mainly interacts with the concave surface of PscG (Figure 1b). Nevertheless, the stabilization of the complex through a large interaction surface between PscG and PscE (Figure 1c) was shown to be essential for the T3SS functioning as residues mutations at the interface disrupt complex formation and abolish T3SS-mediated cytotoxicity. ${ }^{20}$ This

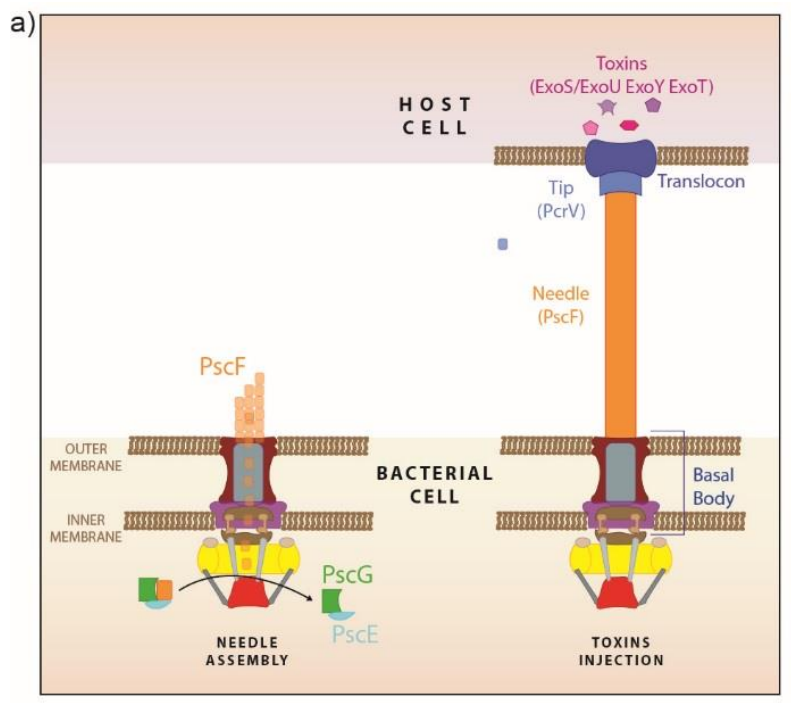

qualified this protein-protein interface as a valuable target for T3SS-based antivirulence drugs.

Herein, we describe the discovery of new bioactive molecules able to inhibit the T3SS assembly. Indeed, we have developed an in vitro screening assay based on the interaction between PscG and PscE, which is essential for PscF stabilization. Protein-protein interaction is an underrepresented target class of small molecules because large surface interaction must be inhibited while meeting the challenge of specificity. ${ }^{21-}$ 23 The interaction surface between the chaperones PscG-PscE estimated at $1321 \AA^{2}{ }^{18}$ (Figure 1c) represents a challenge for the search of protein-protein interface inhibitors (PPII). ${ }^{24}$ Our approach consisted in linking two different clusters identified as hits by the initial screen to make a series of larger hybrid molecules capable of filling up this surface while evolving toward ligands of higher affinity. Docking algorithms targeting PPII are in the early stages but showed success to identify inhibitors and stabilizers of these interfaces. ${ }^{25,26}$ In our study, several interfacial binding sites in the PscE-PscG complex are identified and characterized and the binding modes of the PPII identified in the screen are proposed. Selection of the best molecules in cellular assays involving multiparametric and orthogonal tests allowed the identification of two closely related compounds that demonstrated antivirulence activity in the Galleria mellonella infection model.

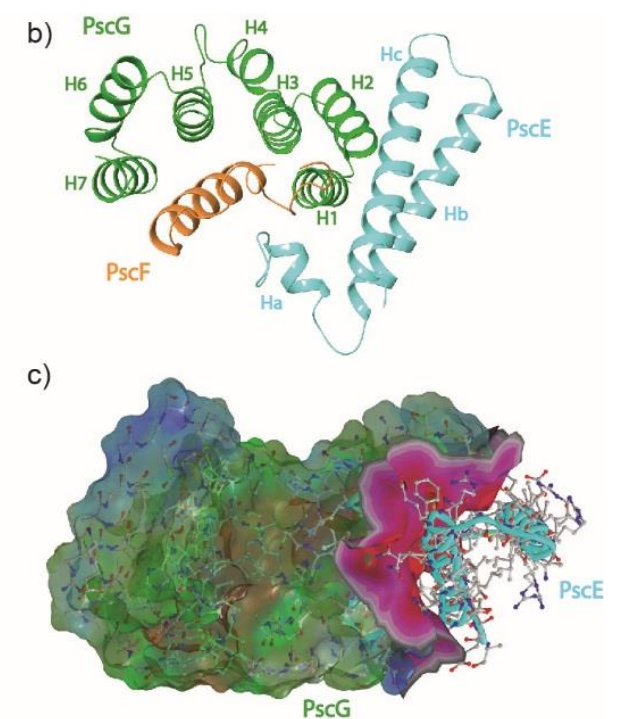

Figure 1: Chaperones PscE and PscG in the context of the Type III Secretion System. (a) Left side, before secretion, the needle protein PscF (in orange) dissociates from the co-chaperones PscG-PscE and auto-assembles to form a needle-like structure. Then, right side, PcrV forms the needle tip and the translocon inserts into the eukaryotic plasma membrane to allow the injection of the toxins. (b) Cartoon representation of the PscE-PscF55-85-PscG complex (PDB ID: 2UWJ). PscE, PscG and PscF chains are respectively represented as cyan, green and orange ribbons. (c) Interaction surface between PscE (Ribbon and lateral chains) and PscG (solid surface). The PscG surface color ranges from blue to brown for a hydrophilic to lipophilic affinity, the interaction surface has magenta gradation for relief perception enhancement.

\section{- RESULT AND DISCUSSION}

Identification of hit molecules from different chemical families. Disruption of PscE-PscG interface was shown to impede the T3SS functioning. In order to identify compounds capable of inhibiting the interaction between the proteins PscG and PscE, an ELISA-based assay was developed using the individually produced and purified recombinant proteins (Figure 2a). PscG was immobilized onto ELISA plates and the screened molecules were incubated; then PscE was added. The presence of the 
PscE-PscG complex was detected using mouse antiPscE antibodies and secondary antibodies. The ability of this assay to identify hit molecules was evaluated by determining the $Z^{\prime}$-factor ${ }^{27}$ using PscE or PBS as positive and negative controls, respectively. The Z'factor of 0.58 clearly indicated that a high-throughput screening could be undertaken. Two chemical libraries were screened: the Prestwick Chemical Library ${ }^{\circledR}$ (1,280 compounds) that mostly contains approved drugs (or compounds under pre-clinical and clinical development) with known safety and bioavailability, and the other one composed of a set of 120 natural product-like compounds representative of our laboratory's expertise (in-house library). A primary screening was performed at a compound concentration of $50 \mu \mathrm{M}$. By setting the threshold at $40 \%$ inhibition, fourteen compounds were identified in the Prestwick collection and one in the laboratory collection (Table S1). Among Prestwick's most efficient hits, clioquinol (Scheme 1) was selected for further work because the hydroxyquinoline scaffold was elsewhere identified as effective in inhibiting the T3SS in P. aeruginosa. ${ }^{11,28} \mathrm{In}$ addition, the chemical feasibility to directly incorporate an alkyne function on clioquinol makes it particularly suitable for subsequent coupling by click reaction. Compound $\mathbf{1}$ from the in-house library was also identified as a hit and belongs to the 3-alkyl pyridine pyridinium alkaloid (3-APPA) family. ${ }^{29}$ This type of molecule is particularly suitable for diversification, especially in length and size. ${ }^{30,31}$

Scheme 1. Clioquinol and 3-APPA 1 as best hits from Prestwick's and in-house natural product-like chemical libraries, respectively and synthesis of new clioquinol derivatives according to Cironi et al.

The combination of hit molecules is beneficial to target the large interaction surface. To increase the affinity of our two selected hits, we combined them into a larger hybrid analogue that would potentially better fill the interaction surface between the two chaperones PscG and PscE. To this end, an approach based on a Split/Mix/Click sequence was implemented (Scheme 2 ). To join the hits, an alkyne group was set on clioquinol (Scheme 1) (32 $^{32}$ and an azide group on the 3APPA derivatives (Scheme 2). Seventeen 3-APPA $\mathbf{1 1}\left(\mathbf{n}, \mathbf{n}\right.$ ') were synthesized, ${ }^{30,31}$ then coupled with $\mathbf{3}$ according to a tandem deprotection/click conversion ${ }^{33}$ to give seventeen hybrid 3-APPA/clioquinol 12(n,n').
This series of new products 2, 3, 4, 11(n,n') and 12(n,n') was evaluated by ELISA (Table S2). For acetylated clioquinol derivatives $\mathbf{2}, \mathbf{3}$ and $\mathbf{4}$, the presence of an acetate group does not disrupt activity. This result is particularly interesting because the observed inhibition properties are not related to the metal chelating property of the hydroxyquinoline unit of clioquinol. Several 3-APPA 11(n,n') showed good ability to inhibit the PscG/PscE interaction similarly or even better than acetylated clioquinol dervirative and clioquinol.

Scheme 2. Split/Mix/Click synthetic route to obtain 3APPA 11(n,n') and hybride 3-APPA/acetylated clioquinol $12(\mathbf{n}, \mathbf{n}$ ')

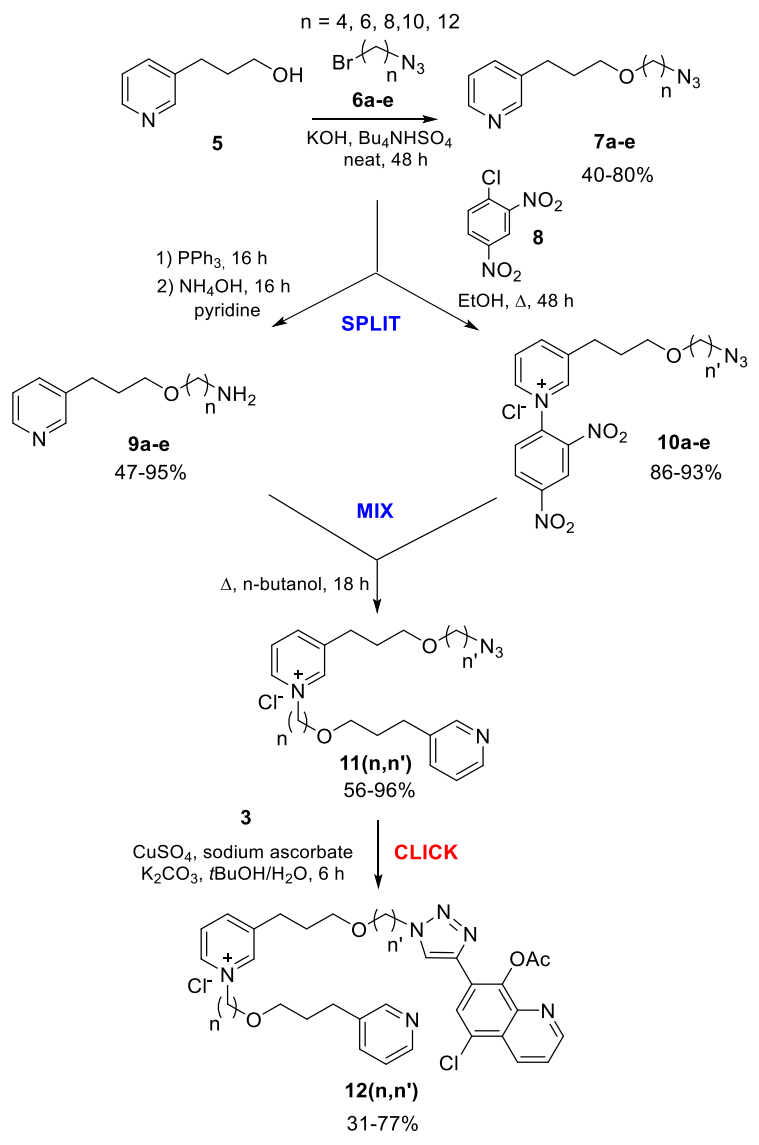

While the inhibitory effects of clioquinol and its $\mathbf{2 - 4}$ derivatives are homogeneous (Figure $2 \mathrm{~b}$ ), a disparity is observed for 3-APPA 11(n,n') and hybrid molecules $\mathbf{1 2}(\mathbf{n}, \mathbf{n}$ '), which does not allow a clear structure-activity trend to be established. With regard to the effect of associating two different inhibitors that gave the 17 hybrid molecules 12(n,n'), we observed that five of them have an increased efficacy compared to each of the two original inhibitors. In the 11(n,n') family, only one molecule $(\mathbf{1 1}(\mathbf{6 , 6}))$ showed a marked higher activity than clioquinol, the best primary hit.

Among the synthesized molecules, nineteen analogues from the acetylated clioquinol, 11(n,n') and 12(n,n') families were chosen for subsequent characterization steps (Table S2), including 18 high and 
mid-range inhibitors and one inactive compound 11(8,4).

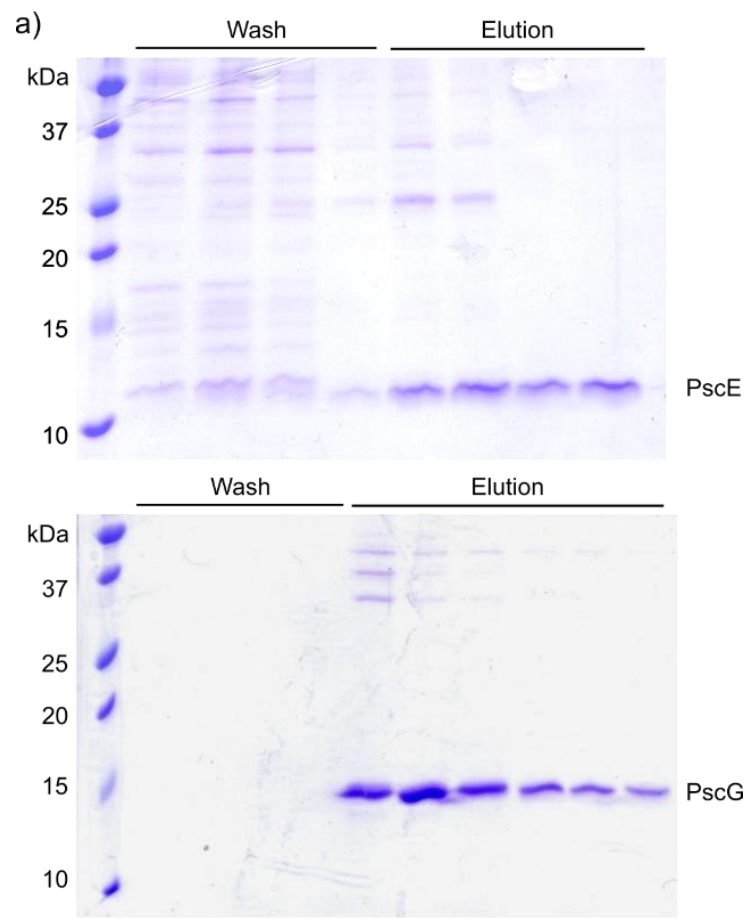

b)

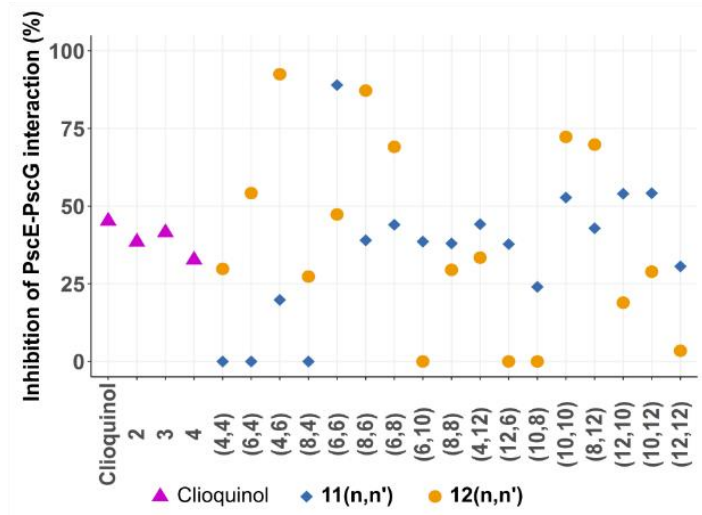

Figure 2: Screening of chemical compounds inhibiting PscE-PscG interaction. (a) PscE and PscG were purified by affinity chromatography and fractions obtained in different steps (wash and elution) were analyzed by SDSPAGE followed by Coomasie staining. (b) Inhibition of PscE-PscG interaction revealed by ELISA for clioquinol or acetylated analogues (red triangle), 11(n,n') (blue

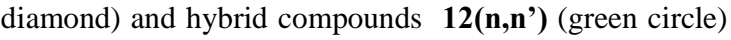
at $50 \mu \mathrm{M}$.

Possible binding modes of PscE-PscG interface inhibitors. To provide structural hypotheses regarding the inhibition mechanism of the hits, molecular docking calculations were performed. Free PscE and PscG polypeptides were modelled from the crystallographic ternary complex PscE-PscF-PscG (PDB ID: 2UWJ) ${ }^{19}$ which is illustrated in Figure 1b. PscF is inserted within the concave surface of PscG, where it interacts through numerous interactions with helices $\mathrm{H} 1 \mathrm{H} 3 \mathrm{H} 5 \mathrm{H} 7$ of PscG and with the N-terminus part of PscE. The PscEPscG interface mainly involves helices $\mathrm{H} 1$ and $\mathrm{H} 2$ of PscG and all three helices of PscE ( $\mathrm{Ha}, \mathrm{Hb}$ and $\mathrm{Hc}$ ) and it is stabilized by hydrophobic interactions and by soft hydrogen bonds. As the ELISA tests were performed with free PscE and PscG, these chains were subjected to short molecular dynamics (MD) of $30 \mathrm{~ns}$ prior to molecular docking calculations (see Figure S1, calculations details and MD results in Supporting Information).

The conformations of PscE and PscG corresponding to $30 \mathrm{~ns} \mathrm{MD}$ were minimized and selected for docking calculations of the 19 hits. The whole PscE chain was considered as a receptor site. For PscG, of larger size, four druggable binding sites (S1, S2, S3 and S4) were identified using Sitemap algorithm ${ }^{34}$ (see Figure S2 and Table S3 in Supporting Information). The docking calculations were carried out as described in the Supporting Information.

To take into account the diversity of the sizes of the compounds the ligands were ranked according to the Glide ligand efficiency score, which is the docking score divided by the number of heavy atoms. The resulting docking scores are rather low with a maximum of $6.5 \mathrm{kcal} / \mathrm{mol}$ (i.e. a maximum of Glide ligand efficiency around $-0.3 \mathrm{kcal} / \mathrm{mol}$ ), consistent with compounds binding at interfaces and thus partially exposed to water. In Figure 3 are illustrated the best poses of each chemical family in each binding site. Interestingly, clioquinol is among the top five bestranked ligands in all the binding sites while the 3-APPA 11(n,n') and 3-APPA/acetylated clioquinol 12 (n,n') derivatives show slightly lower binding scores. However, this should not be over-interpreted, due to the difficulty of taking into account long and flexible ligands in docking algorithms. ${ }^{25,26}$

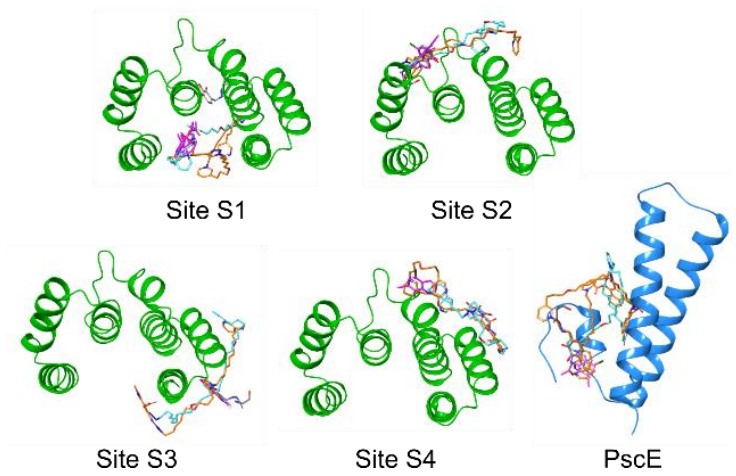

Figure 3: Best poses of each chemical family. The protein backbones are represented as blue and green ribbons for PscE and PscG, respectively. Ligands are color coded: in magenta Clioquinol, in cyan 11(n,n'), in orange $12\left(n, n^{\prime}\right)$.

In PscE, the 11(n,n') and 12(n,n') analogues preferentially bind at the interface between helix $\mathrm{Ha}$ and helices $\mathrm{Hb}$ and $\mathrm{Hc}$, in the close vicinity of PscG. The PscE surface exposed to solvent in the ternary 
complex is strongly polar (R24, R35, R36, R40, R55, D70, E58) and thus does not attract hydrophobic moieties.

Among the binding sites identified on PscG, only sites S3 and S4 lie at the interface with PscE. However, we considered the possibility that the compounds could behave as allosteric inhibitors and bind at exosites, by trapping the protein in a conformation unsuitable to assemble with the other chaperon. The $\mathrm{S} 3$ site is mainly hydrophobic with PscG residues L12, A13, C21, A25 and I28: in the ternary complex it faces PscE residues A53, G56, G57, I60 thus forming a large hydrophobic cluster. In this site, the best poses of $\mathbf{1 1}(\mathbf{n}, \mathbf{n}$ ') and 12(n,n') have a highly preserved binding mode since their pyridinium moiety is inserted between $\mathrm{H} 1$ and $\mathrm{H} 2$ helices, where it can have complementary electrostatic interactions with PscG E24 residue. The apolar linkers

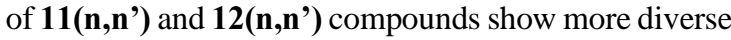
binding modes and are stabilized by PscG residues L9, L12, C21, I28 and W31.

Selection of the molecules through cellular screens. First, the bacterial growth in presence of the hit compounds was monitored in order to exclude compounds with strong antibiotic activity. Second, the toxicity and efficacy of the molecules were evaluated on two assays using the human epithelial pulmonary cell line A549. Cell viability was measured in presence of the molecules, as well as the ability of the molecules to protect these cells from ExoU-mediated $P$. aeruginosa cytotoxicity. All the eighteen molecules, along with the clioquinol, as reference (Table S2), were tested at $3 \mu \mathrm{M}, 10 \mu \mathrm{M}$ and $30 \mu \mathrm{M}$ in triplicates. The data were processed as described in the Experimental section and represented in radar plots (Figure 4).
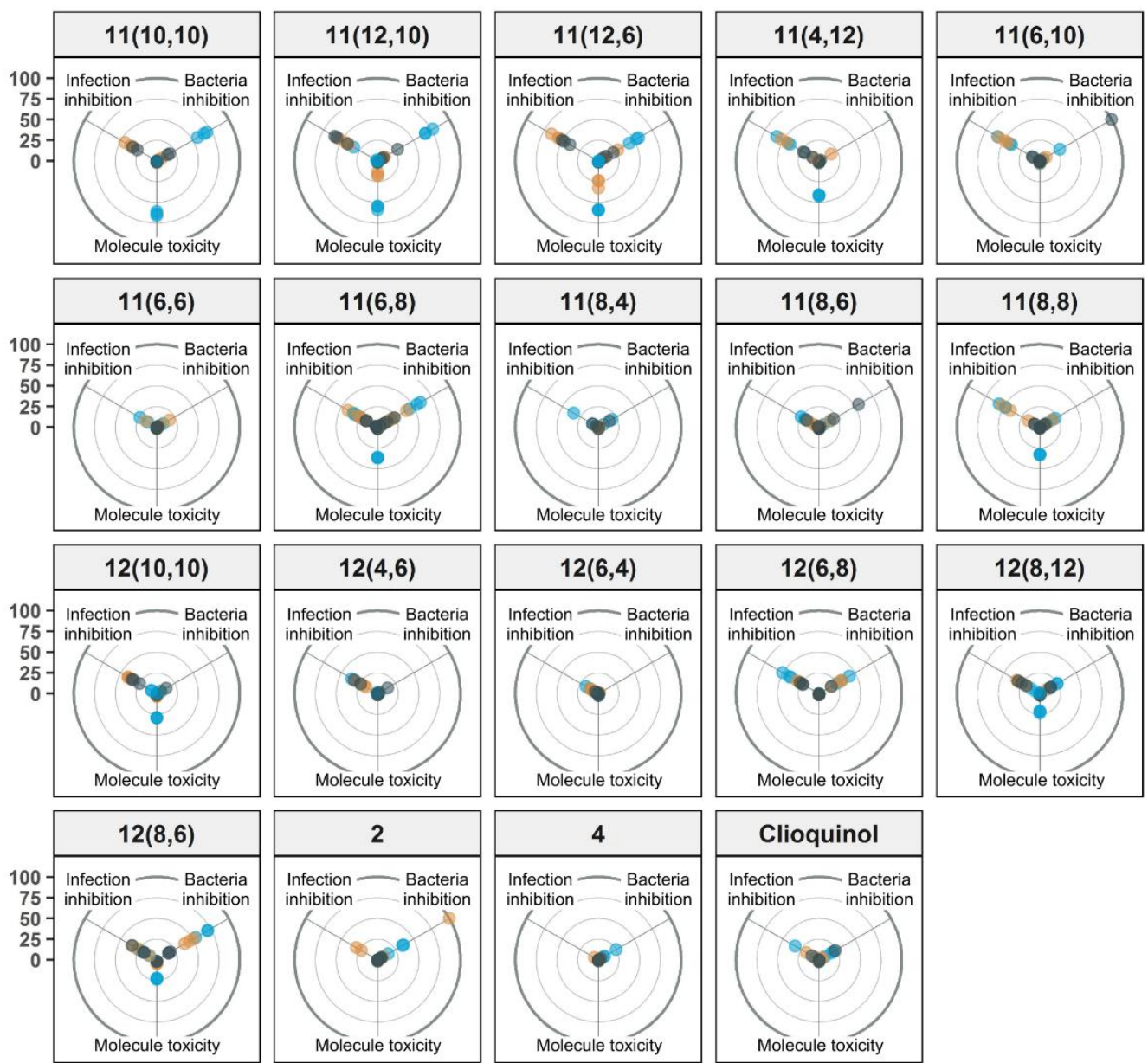

Molecule toxicity
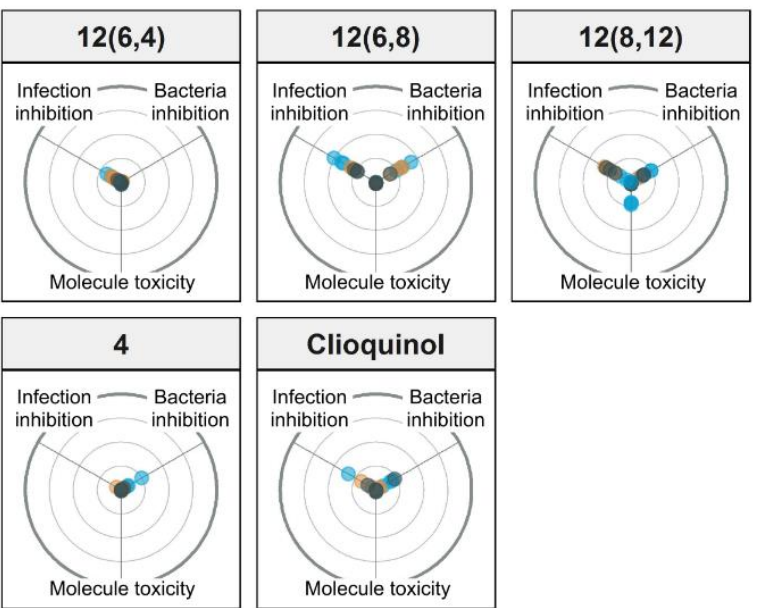

Concentration $\bullet 3 \mu \mathrm{M} \quad \bullet 10 \mu \mathrm{M} \quad \bullet 30 \mu \mathrm{M}$

Figure 4:

Cellular characterization of 19 selected compounds. The direct toxicity on eukaryotic cell (molecule toxicity) of 19 selected compounds and their effects on bacterial growth (bacteria inhibition) and ExoU-induced cytotoxicity (infection inhibition) were assessed in triplicates at 3,10 and $30 \mu \mathrm{M}$. All experimental points are represented on radar plots (coordinate polar). The three axis correspond to the three assays: bacterial growth inhibition monitored by $\mathrm{OD}_{600}$, cell toxicity and infection inhibitions detected by PI incorporation. The four circles correspond to 25, 50, 75 and $100 \%$ of inhibition. 
Measurements of the optical density of the bacterial cultures at $600 \mathrm{~nm}\left(\mathrm{OD}_{600}\right)$ during $16 \mathrm{~h}$ showed that most of the compounds actually present a significant effect on bacterial growth while only one third of them induced less than $25 \%$ inhibition of bacterial growth at the highest $(30 \mu \mathrm{M})$ concentration.

Detection of Propidium Iodide (PI) incorporation into A549 eukaryotic cells incubated for $5 \mathrm{~h}$ with the molecules showed profiles of variable cytotoxicity, more than half of which did not exhibit cytotoxicity to mammalian cells in this time period.

In order to assess the capacity of compounds to protect eukaryotic cells from $P$. aeruginosa T3SSdependent cytotoxicity, we used the ExoU-positive PA103 strain that induces rapid eukaryotic cell death revealed by PI labeling. In this third assay, the compounds displayed varying degrees of inhibition of bacteria-mediated cytotoxicity, except compound 4 that was ineffective (see Scheme 1). For a number of hits, the protective effect was correlated with inhibition of the bacteria growth, which would indicate an undesired antibiotic-like activity pattern. For seven hits a lack of dose-response in this protection assay was observed. Strikingly, most of these compounds present a direct toxicity towards eukaryotic cells at high concentration. Thus, the direct cytotoxicity could induce IP entry in the cells that would compensate the possible protective effect from bacteria-induced cytotoxicity, explaining the apparent lack of dose-response effect in the protection assay.

Based on these results, four compounds showing no or poor bactericidal activity 11(6,6), 12(4,6), 12(6,4) and clioquinol were selected for further characterization and structure-activity comparison in another set of assays. These four compounds exhibited less than $25 \%$ inhibition of bacterial growth, no cell toxicity and prevented ExoU-dependent cell death suggesting an inhibition of the virulence of the PA103 strain towards mammalian cells (Figure 4). The three chemical families are represented in these four compounds including the clioquinol reference, one compound of 3-APPA cluster and two hybrid compounds.

Further cellular characterization of four molecules. $P$. aeruginosa strains inject either ExoU or ExoS and the majority of the clinical strains are ExoS ${ }^{+}$. ExoS-expressing strains provoke disruption of host cytoskeleton through hijacking of cell signaling. ${ }^{35}$ Here, we developed three additional orthogonal phenotypic assays employing the ExoS-positive $P$. aeruginosa CHA strain that injects ExoS to evaluate the potency of the selected compounds in a different bacterial context and to further investigate their mechanism of action. First, the ExoS secretion in presence of the molecules was monitored. To that aim, a secretion assay was employed in which the $\beta$ lactamase fused to the $\mathrm{C}$-terminal ExoS was quantified in the extracellular media. Then, cell protection was evaluated by two means: in a first experiment cells membranes were labelled and cell shrinkage was quantified by measuring decrease of cell confluence. In a second experiment, the recently described CLIQ-BID (bright nuclei) method was employed to reveal both the cellular damages caused by the bacteria and the toxicity or cell stress due to the compounds on their own. ${ }^{36}$

Similarly as before, the four compounds were tested at three concentrations and in triplicate and the results are presented in radar plots (Figure 5).

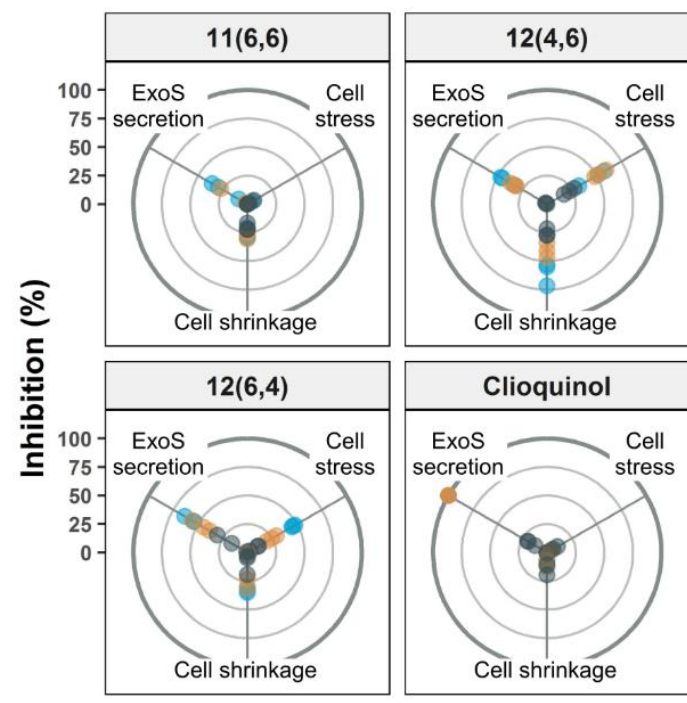

Concentration $\bullet 3 \mu \mathrm{M} \bullet 10 \mu \mathrm{M} \quad \bullet 30 \mu \mathrm{M}$

Figure 5. Selection of compounds with anti-T3SS activity. The effect of four selected compounds was assessed in triplicates at 3,10 and $30 \mu \mathrm{M}$ by three orthogonal assays. All experimental points are represented on radar plots (coordinate polar) in percentage of inhibition. Three axis correspond to 3 independent assays: ExoS secretion, Cell stress and Cell shrinkage. The four circles correspond to $25,50,75$ and $100 \%$ of inhibition. The secretion of ExoS-Bla reporter protein was evaluated by measuring beta-lactamase activity. The cell stress was monitored by bright nuclei detection and cell shrinkage was quantified by cell area measurement, as described in the Experimental section.

All the tested compounds were able to impair the secretion of ExoS in the ExoS-Bla secretion assay, clearly revealing an inhibition of the T3SS in living bacteria. On the other hand, while all the four compounds protected cells from the cell shrinkage induced by the ExoS toxin, only 12(4,6) and 12(6,4) exhibited protection against cell stress as shown using the CLIQ-BID assay. It is likely that the two other coumounds, clioquinol and 11(6,6), are slightly harmful for the eukaryotic cells, inducing a cell stress that may mask their anti-virulence activity. Indeed, one advantage of the CLIQ-BID method is to sensitively detect compounds toxicity, allowing to reject molecules whose toxic effects could prevail over the protective effect ${ }^{36}$ while the incorporation of propidium iodide (Figure 4) may only detect molecules markedly lethal for the eukaryotic cells. 
From these results, clearly two compounds out of the four tested, 12(6,4) and 12(4,6), displayed inhibitory activities in the three specific assays. Thus, 12(6,4) and 12(4,6) were selected as "lead" compounds. Interestingly, both $\mathbf{1 2}(\mathbf{6 , 4})$ and $\mathbf{1 2}(4,6)$ belong to the combination cluster and their structures are very close to each other; notably, the total length of the linkers between the pyridine and the clioquinol part is the same.

$12(6,4)$ and $12(4,6)$ specifically inhibit secretion through the T3SS apparatus. In order to assess the specificity of the T3SS inhibition by the lead compounds (chemical structures shown on Figure 6a), secretion experiments on bacteria were performed in the presence of molecules at $5 \mu \mathrm{M}, 12.5 \mu \mathrm{M}$ and $30 \mu \mathrm{M}$. The secretion of three T3SS-exported proteins ExoS, ExoT and PopD was monitored by Western Blot (Figure 6b). A strong inhibition of ExoS and ExoT secretion could be observed at 12.5 and $30 \mu \mathrm{M}$, with a threshold effect, while the inhibition of PopD secretion was correlated to the compound's concentration. Quantification of the western-blot analysis was made on three independent experiments (Figure 6c), confirming the dose-dependent inhibition. IC50 could be estimated to $10 \mu \mathrm{M}$ for the secretion of the effectors ExoS and ExoT and $20 \mu \mathrm{M}$ for the secretion of translocator PopD. In order to get more precise IC50 values, the inhibition of the ExoS-Bla secretion was enzymatically measured (Figure $6 \mathrm{~d}$ and e). In this assay, the IC50 were 15 and $9 \mu \mathrm{M}$ for $\mathbf{1 2 ( 6 , 4 )}$ and 12(4,6), respectively. Taken together, the results obtained in Western blot and in the ExoS-Bla secretion assay do not indicate a significant difference between 12(6,4) and 12(4,6).

The molecule toxicity toward bacteria, first assessed on the PA103 strain (Figure 4) was further examined on the CHA strain in order to ascertain that the reduced T3SS secretion was not indirectly due to a decrease of bacteria fitness. For this purpose, the bacterial growth was monitored for $24 \mathrm{~h}$ in the presence of the lead compounds (Figure 6f). The growth curves were indistinguishable in all tested conditions, except at the end of the stationary phase where a faint decrease was observed in the presence of $12(6,4)$ or $12(4,6)$. In addition, the bacterial intracellular ATP level in the exponential phase was quantified after growth (Figure $6 \mathrm{~g}$ ), displaying no difference in the presence or absence of the compounds. Furthermore, no inhibition of Escherichia coli DH5 $\alpha$ and Yersina enterocolitica growth was observed (see Figure S5a in Supporting Information). While the T3SS architecture and functioning are relatively conserved among Gramnegative pathogens, neither $12(6,4)$ nor $12(4,6)$ were able to inhibit the cell shrinkage caused by $Y$. enterocolitica whose T3SS is phylogenetically close to the one of $P$. aeruginosa ${ }^{37}$ (see Figure S5b in Supporting Information). Consequently, 12(6,4) and 12(4,6) are anti-virulence compounds specifically targeting $P$. aeruginosa and do not affect bacterial viability. 
a)

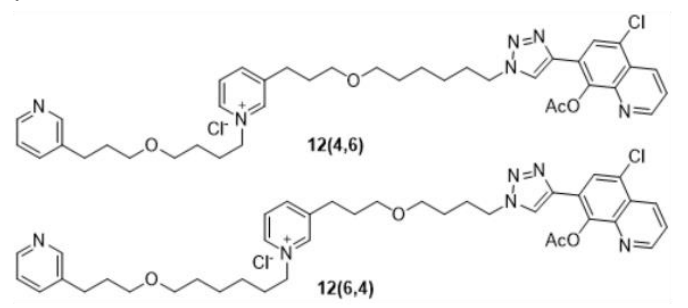

c)

\begin{tabular}{|l|c|c|c|}
\hline & $\mathbf{I C}_{50}$ ExoS $(\mu \mathrm{M})$ & $\mathbf{I C}_{50}$ ExoT $(\mu \mathrm{M})$ & $\mathbf{I C}_{50}$ PopD $(\mu \mathrm{M})$ \\
\hline $\mathbf{1 2}(6,4)$ & $9.8 \pm 2.7$ & $11.5 \pm 0.8$ & $21.0 \pm 4.4$ \\
\hline $\mathbf{1 2}(\mathbf{4}, \mathbf{6})$ & $10.0 \pm 1.6$ & $13.4 \pm 4.8$ & $28.1 \pm 9.2$ \\
\hline
\end{tabular}

d)

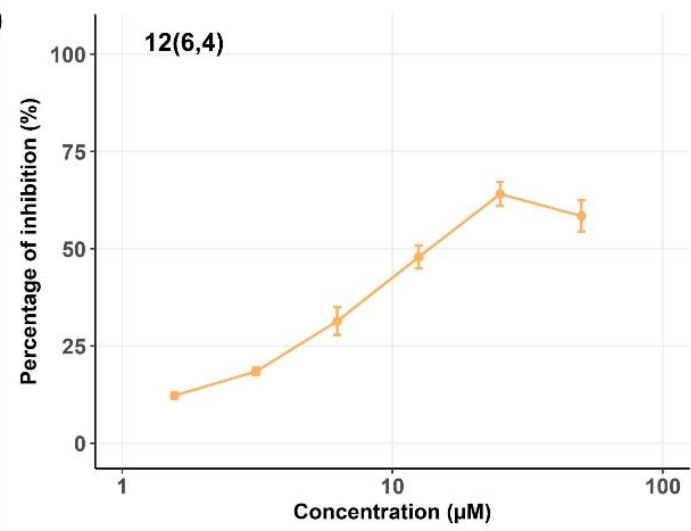

f)

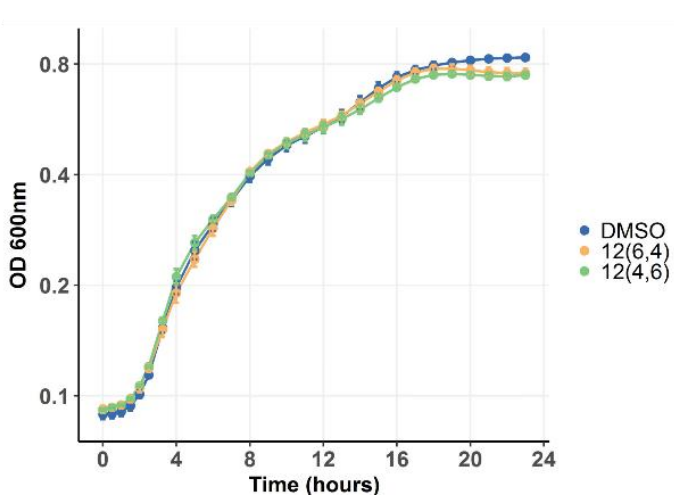

b)
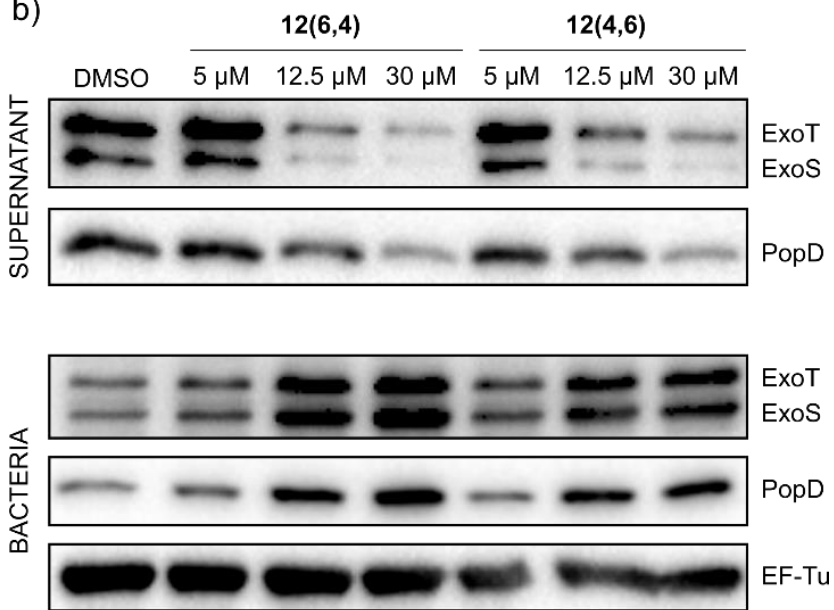

e)

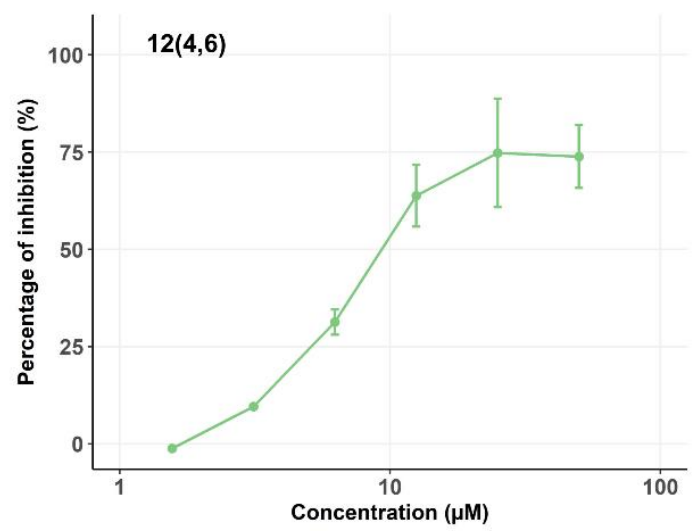

g)

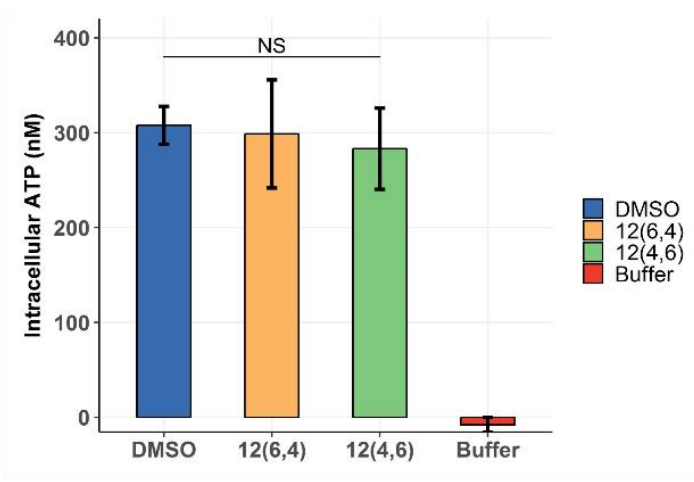

Figure 6: 12(6,4) and 12(4,6) inhibit in vitro secretion of T3SS proteins and do not affect bacterial fitness. (a) Chemical structures of 12(6,4) and 12(4,6). (b) $P$. aeruginosa CHA was grown in the presence of $\mathbf{1 2}(\mathbf{6 , 4})$ or $\mathbf{1 2}(\mathbf{4 , 6})$ at $5,12.5,30 \mu \mathrm{M}$ or DMSO. The secretion of two effectors ExoS, ExoT and one translocator PopD was detected by western blot. EF-Tu is a loading control. (c) Western-Blot quantification of three independent experiments allowed the determination of $\mathrm{IC}_{50}$ of the compounds for the secretion of the three proteins. (d and e) ExoS-Bla secretion in the presence of 12(6,4) or 12(4,6) was quantified using nitrocefin as a substrate of the beta-lactamase. Results are expressed in percentage of inhibition considering the wild-type and $\Delta p s c F$ CHA strains as positive and negative controls, respectively. (f) The growth of $P$. aeruginosa CHA in LB medium containing DMSO, 12(6,4) or 12(4,6) at $12.5 \mu \mathrm{M}$ was monitored for $24 \mathrm{~h}$ by measuring the optical density at $600 \mathrm{~nm}$. $(\mathrm{g}) \mathrm{The}$ concentration of intracellular ATP of $P$. aeruginosa CHA was determined in the exponential phase growth in the presence of DMSO, 12(6,4) or 12(4,6). No significant difference was found.

The architecture of the flagella machinery is similar to the injectisome T3SS structure and its functioning is also dependent on ATP hydrolysis and the protonmotive force gradient. ${ }^{37}$ Therefore, to further assess the specificity of the lead compounds, we assessed the flagella-dependent swimming motility of $P$. aeruginosa in the presence of the compounds on low-density agar plates and compared to a mutant devoid of functional flagella (Figure 7a). No inhibition could be detected, indicating that $12(4,6)$ and $12(6,4)$ did not affect the flagella activity.

Besides, the Type 4 pilus (T4P) is also a multiprotein appendage that spans the inner and outer membranes as the T3SS and the flagella. The twitching 
motility, which is T4P-dependent, ${ }^{38}$ was thus observed in the presence of the compounds or in a deletion mutant of a gene essential for T4P function (Figure 7b). Similarly to the flagellum, the compounds did not inhibit the T4P. This further indicate that the observed inhibition of the T3SS-mediated intoxication does not result from membrane destabilization that would elseways affect other membrane-embedded machineries.

Biofilm formation by $P$. aeruginosa is an important clinical feature and is the target of anti-virulence strategies. It is triggered in conditions opposite to those in which the T3SS is active and it is considered to be involved in chronic rather than acute infections, as

a)
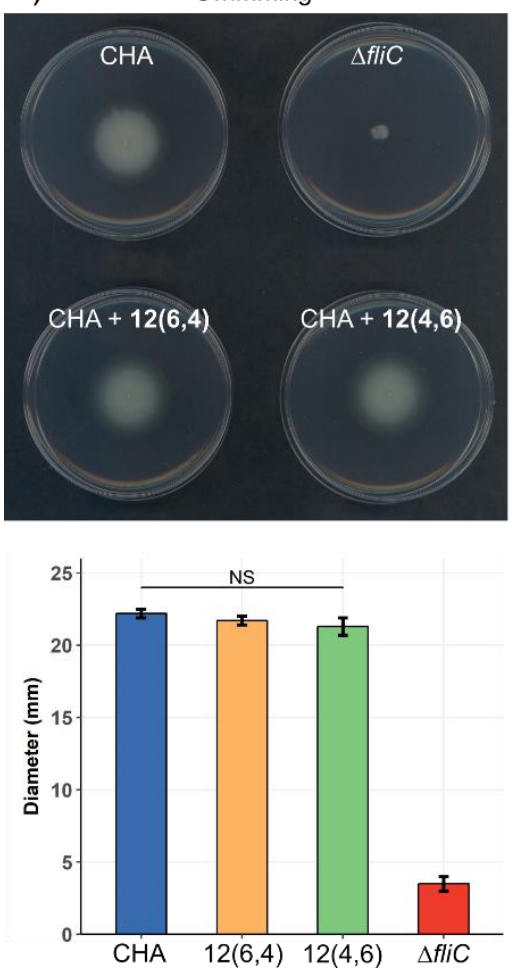

b)
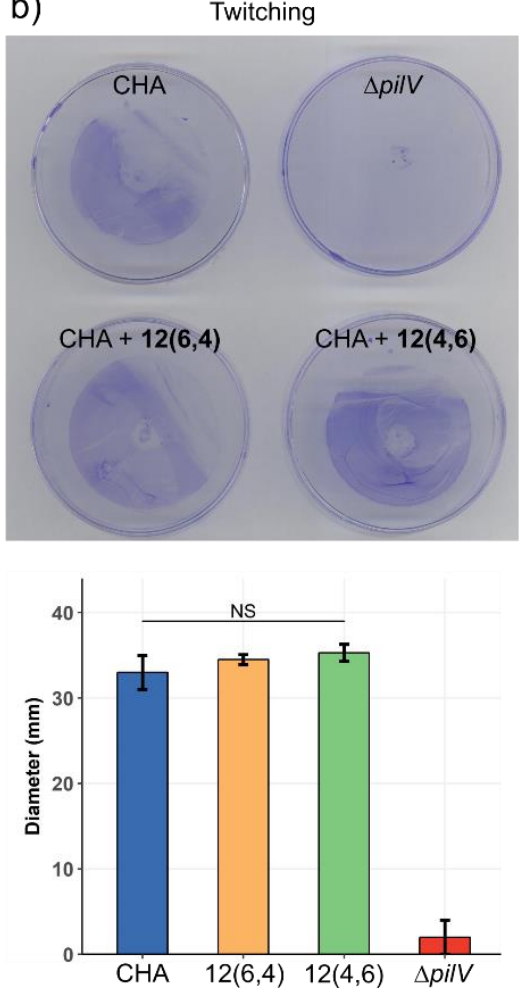

opposed to T3SS. ${ }^{6}$ Therefore, the effect of the lead molecules on biofilm formation was investigated in order to check that T3SS inhibition would not lead to biofilm increase and to complement our view of their biological activities. The wild-type CHA strain producing a low level of biofilm, it was used a negative control while the $\Delta r s m A$ strain that exhibits a high biofilm level ${ }^{39}$ was treated with DMSO or the molecules (Figure 7c). Treatment with either molecule did not result in any significant difference in biofilm formation. Taken together, these findings confirmed that the two lead compounds $12(6,4)$ and $12(4,6)$ are specific inhibitors of the T3SS. The possible binding mode of $\mathbf{1 2}(\mathbf{6 , 4 )}$ in $\mathrm{S} 3$ site is represented in Figure $\mathrm{S} 4$.

Figure 7: 12(6,4) and 12(4,6) do not affect flagellar- nor T4 pili- dependent motility nor biofilm formation. Two different types of bacteria motility were assessed on agar plates: the swimming and twitching motilities that are respectively dependent on flagella and T4 pili. (a) Swimming assay of $P$. aeruginosa CHA strain in the presence of $\mathbf{1 2 ( 6 , 4 )}$ or $\mathbf{1 2}(4,6)$ at $12.5 \mu \mathrm{M}$ or DMSO. The strain $\triangle f l i C$ devoid of functional flagella was used as a negative control. (b) Twitching assay of $P$. aeruginosa CHA strain in the presence of $\mathbf{1 2}(\mathbf{6 , 4})$ or $\mathbf{1 2}(\mathbf{4 , 6 )}$ at $12.5 \mu \mathrm{M}$ or DMSO. The strain $\Delta p i l V$ devoid of functional pili was used as a negative control. The diameters of the motility rings were measured for three independent replicates. (c) Biofilm formation was assessed using the high-biofilm strain CHA $\Delta r s m A$ grown in static culture for 24 hours in the presence of 12(6,4) or 12(4,6) at $12.5 \mu \mathrm{M}$ or DMSO. The low-biofilm wild-type CHA strain was used as a negative control. Biofilm were stained with crystal violet for visualization and quantified after dissolution and absorbance measurement of three independent replicates. The graphics present the means and standard deviations for the different assays. The only statistically significant differences are observed for the controls strains.

Protection of animal model from bacterial infection. Before injection into animals, medium term toxicity toward eukaryotic cells was evaluated. Indeed, the toxicity of $12(4,6)$ and $12(6,4)$ was evaluated with the A549 cells death assay, detecting PI incorporation during $5 \mathrm{~h}$ (Figure 4). This incubation duration is usually used in comparable studies ${ }^{28}$ and no toxicity c)
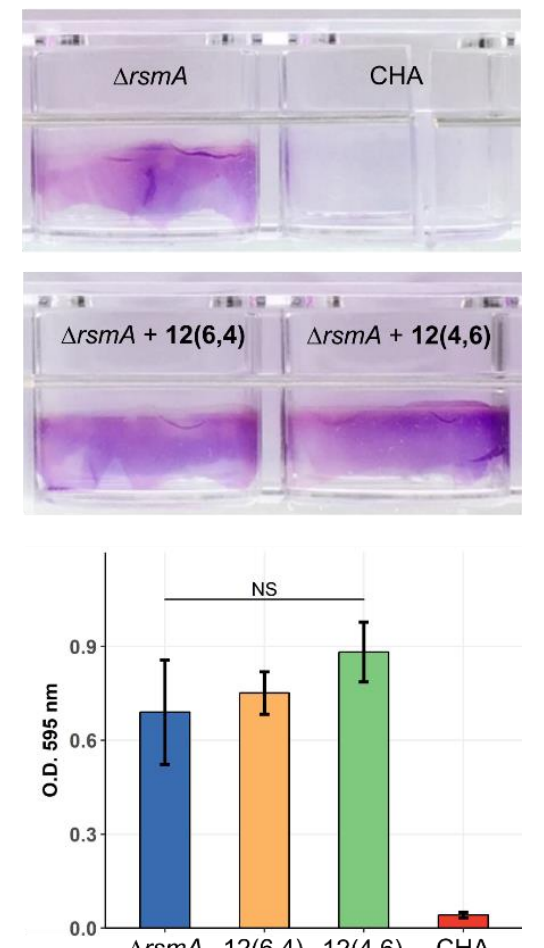
and insects ( $G$. mellonella) can be correlated. ${ }^{40}$ Moreover, G. mellonella is a good model to evaluate the efficacy of antimicrobial agents. ${ }^{41}$ Therefore a dose of 50 wild-type bacteria was injected into the larvae and 30 min later, the compounds, or only compounds' solvant DMSO, were subsequently injected. As a control, larvae were infected with a $P$. aeruginosa deletion mutant of the gene $p s c E$, essential for the T3SS, and then injected with DMSO. The survival of the insects was monitored for $20 \mathrm{~h}$ (Figure 8). Infection with the $\Delta p s c E$ mutant devoid of a functional T3SS induced a delayed larvae death compared to infection with the wildtype strain. However, these $\Delta p s c E$ bacteria are still pathogenic, due to the presence of other virulence factors. Remarkably, injection with either $\mathbf{1 2}(\mathbf{6 , 4 )}$ or $\mathbf{1 2}(4,6)$ could significantly improve the survival of larvae, although to a lesser extent than deletion of the $p s c E$ gene, thus indicating that these inhibitors have a partial protective efficacy on Galleria mellonella model.

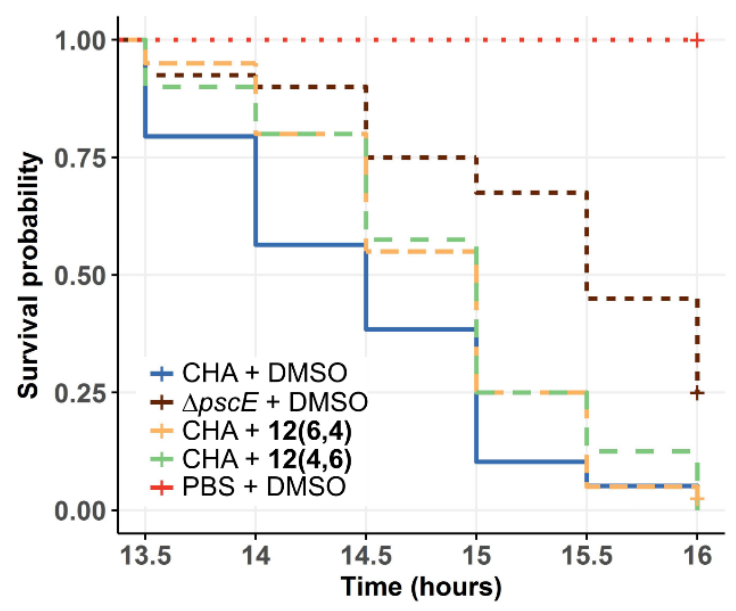

Figure 8: 12(6,4) and 12(4,6) protect Galleria mellonella from $P$. aeruginosa infection. Insect larvae $(n=40)$ were infected with a dose of 50 bacteria and were injected $1 \mathrm{~h}$ later with $\mathbf{1 2}(\mathbf{6 , 4}), \mathbf{1 2}(\mathbf{4 , 6 )}$ at $12.5 \mu \mathrm{M}$, or DMSO. The strain $\triangle p s c E$ was used as a negative control. The survival of the insects was monitored for $20 \mathrm{~h}$ and survival curves were represented with a Kapan-Meier plot. A significant difference (p-values $=0.048$ and 0.041 for $12(6,4)$ and 12(4,6), respectively) between the larvae that received DMSO and the compounds indicates that $\mathbf{1 2}(\mathbf{6 , 4 )}$ and $\mathbf{1 2}(4,6)$ provide partial protection from $P$. aeruginosa infection.

\section{- CONCLUSIONS}

In this study, we designed an automated target-based screening to identify inhibitors targeting the interaction of two cognate chaperones PscE and PscG of the T3SS needle subunit protein PscF. The acetylated clioquinol and 3-APPA scaffolds were selected as the basis for building new, larger hybrid analogues. In some cases, their combination resulted in higher inhibition efficiency of the protein-protein interaction. Based on this in vitro evaluation, 19 compounds from the three clusters (acetylated clioquinol, 3-APPA 11(n,n') and hybrid 3-APPA/acetylated clioquinol 12(n,n')) were further characterized by several biochemical and cellular assays, allowing to select two lead compounds 12(6,4) and 12(4,6). These compounds have no deleterious effects on bacterial growth, are not cytotoxic and displayed protective effects on A549 eukaryotic cell line infected by two different $P$. aeruginosa strains.

$12(6,4)$ and $12(4,6)$ also partially protect $G$. mellonella against $P$. aeruginosa infection, as shown by a survival experiment. Therefore, this new family of antivirulence compounds, which targets a key proteinprotein interaction in the assembly of the $P$. aeruginosa T3S machinery, helps to propose a new solution to treat bacterial infections that should reduce the development of resistance in this harmful pathogen.

\section{- EXPERIMENTAL SECTION}

Protein purification and automated target-based Screening ELISA assay. 6His-PscE and 6His-PscG were expressed in E. coli BL21 (DE3) Star using pET plasmids. ${ }^{18}$ E. coli strains were grown in $1 \mathrm{~L}$ of LB broth and induced at $\mathrm{OD}_{600 \mathrm{~nm}}$ of $0.9-1$ for $3 \mathrm{~h}$ at $37^{\circ} \mathrm{C}$. Cells containing 6His-PscE were harvested and resuspended in IMAC buffer (25 mM Tris $\mathrm{pH} 8,500$ $\mathrm{mM} \mathrm{NaCl}$ and $2 \%$ glycerol). Cell suspension was lysed by French press or sonication and centrifuged at $200,000 \mathrm{~g}$ for $30 \mathrm{~min}$. Soluble $6 \mathrm{His}-\mathrm{PscE}$ was purified with Ni-NTA sepharose beads and eluted by three steps of IMAC containing $50 \mathrm{mM}, 100 \mathrm{mM}$ and $500 \mathrm{mM}$ of imidazole. For purification of $6 \mathrm{His}-\mathrm{PscG}$, harvested cells were resuspended in IMAC containing $6 \mathrm{M}$ urea. After centrifugation, solubilized $6 \mathrm{His}-\mathrm{PscG}$ was purified on a HistrapHP column and protein refolding was performed on column by decreasing the urea concentration from $6 \mathrm{M}$ to $0 \mathrm{M}$ in IMAC buffer. 6HisPscG was then eluted by three steps of IMAC containing $100 \mathrm{mM}, 250 \mathrm{mM}$ and $500 \mathrm{mM}$ of imidazole. Both proteins were dialyzed against Tris/NaCl buffer (25 mM Tris, $250 \mathrm{mM} \mathrm{NaCl}$, pH8).

For screening, $50 \mu \mathrm{L}$ of PscG protein at $1 \mu \mathrm{M}$ (for the screening of Prestwick and in-house library compounds) or $2.2 \mu \mathrm{M}$ (for the screening of synthetized analogue compounds) were coated on ELISA NUNC 96 well plates for $8 \mathrm{~h}$ at $4{ }^{\circ} \mathrm{C}$. The wells were then washed three times with $200 \mu \mathrm{L}$ of PBS/0.1\% Tween 20 (PBST) and incubated with $200 \mu \mathrm{L}$ of milk $5 \%$ in PBST overnight at $4{ }^{\circ} \mathrm{C}$. The solution was next removed by aspiration and a mix of $40 \mu \mathrm{L}$ of buffer $(25$ $\mathrm{mM}$ Tris $\mathrm{pH} 8,250 \mathrm{mM} \mathrm{NaCl}), 50 \mu \mathrm{L}$ of PscE at $25 \mu \mathrm{M}$ (screening of library compounds) or $3 \mu \mathrm{M}$ (screening of analogue compounds) and $10 \mu \mathrm{L}$ of compounds prediluted in buffer was added on plates for $4 \mathrm{~h}$ of incubation at room temperature $\left(\mathrm{RT}^{\circ}\right)$. The wells were subsequently washed three times with $200 \mu \mathrm{L}$ of PBST and incubated with $50 \mu \mathrm{L}$ of anti-PscE antibody $\left(1 / 2,000\right.$ in PBST) for $2 \mathrm{~h}$ at $\mathrm{RT}^{\circ}$. Three additional washes with $200 \mu \mathrm{L}$ of PBST were performed before incubation with $50 \mu \mathrm{L}$ of anti-mouse-HRP antibody $(1 / 5,000$ in PBST) for $2 \mathrm{~h}$. The wells were then washed with PBST (three times) and revealed with the TMB kit. The absorbance was read at $450 \mathrm{~nm}$ 
Chemical synthesis of clioquinol, 3-APS and hybrid 3-APS/clioquinol analogues Compound purity was $>95 \%$ (see Supporting Information for synthesis procedures and analysis results)

Molecular modelling/docking (see Supporting Information)

Bacterial Strains and Growth Conditions. $P$. aeruginosa cystic fibrosis clinical strains CHA, its $\triangle p s c E$ and $\triangle p s c F$ mutant, ${ }^{20}$ and the strains expressing ExoS-Bla fusion protein CHA $\triangle$ exoS/ExoS-Bla and CHA $\triangle p s c F /$ ExoS-Bla ${ }^{42}$ have been previously described. Other strains were $P$. aeruginosa PA103, Yersinia enterocolitica MRS40, its $\triangle \mathrm{HOPEMN} \mathrm{mutant}$ and Escherichia coli DH5a. All the bacteria were grown in LB media (Luria Bertani-Difco) at $37^{\circ} \mathrm{C}$ except $Y$. entericolitica strains which were grown at $28{ }^{\circ} \mathrm{C}$. For infection, overnight cultures were diluted in fresh media to OD of 0.1 and culture were grown for 2.5 to $3 \mathrm{~h}$ to reach OD of 1 . Bacteria were then incubated with eukaryotic cells at a multiplicity of infection (MOI) of 10.

Compound dilution and preparation. All the compounds were available at $10 \mathrm{mM}$ in $100 \%$ DMSO stock solutions. They were then serially diluted in DMSO and distributed in 96-well plates (ABgene, $0796,1.5 \mu \mathrm{L}$ per well) at different concentrations with a robotic system (CMBA's customized integrated robotic platform, based on a TECAN's Freedom EVOware® 200 workstation). These plates were used for compounds dilution in culture media (DMSO final concentration of $0.5 \%$ ) to perform automated microscopy.

Cell death. A549 cells were cultured overnight with 5000 cells in $80 \mu \mathrm{L} /$ well in Black $\mu$ clear 384-well plates (Greiner) in RPMI supplemented with $10 \%$ FBS at $37{ }^{\circ} \mathrm{C}$ in a humidified incubator and with an atmosphere of $5 \% \mathrm{CO}_{2}$. For screening, medium was replaced with $60 \mu \mathrm{L}$ of fresh medium containing $0.25 \mu \mathrm{M}$ Syto24 (Life Technologies), $0.5 \mu \mathrm{g} / \mathrm{mL}$ Propidium Iodide (PI) (Sigma Aldrich), P. aeruginosa PA103 at MOI of 10 and in presence of compounds diluted at three concentrations $(30 \mu \mathrm{M}, 10 \mu \mathrm{M}, 3 \mu \mathrm{M})$. The kinetic acquisitions were performed using the automated microscope Incucyte ${ }^{\circledR}$ Zoom System (Essen Bioscience). One image per well was acquired every $45 \mathrm{~min}$ for $5 \mathrm{~h}$ with the $4 \mathrm{X}$ objective. The RED channel was used for PI staining detection, the GREEN channel was used for Syto24 staining and the PHASE image channel was used to monitor cell morphology. The whole system was maintained at $37{ }^{\circ} \mathrm{C}$ and $5 \% \mathrm{CO}_{2}$ in a humidified incubator. The image analysis was performed by using the Basic Analyzer of Incucyte Zoom software. Top-Hat background subtraction was applied and edge split was set to -24 to separate closelyspace objects. The Red Objet Count (1/Well) in RED channel was obtained for the dead cell count (PI incorporation) by applying a threshold of $2.4 \mathrm{Red}$ Calibrated Units (RCU) and a radius of $100 \mu \mathrm{m}$. The Green Objet Count (1/Well) in GREEN channel was obtained for the total cell count at the starting time point by applying a threshold of $12 \mathrm{GCU}$ and a radius of
$30 \mu \mathrm{m}$. Data were used to calculate the percentage of PI positive cells at each time point.

Cell shrinkage. A549 cells were cultured overnight at 12,500 cells in $100 \mu \mathrm{L} /$ well in Black $\mu$ clear 96-well plates (Greiner) in RPMI supplemented with $10 \%$ of FBS. Two hours before infection, cells were washed two times with $100 \mu \mathrm{L}$ of PBS to remove cellular debris before incubation with $100 \mu \mathrm{L}$ of fresh medium containing Dii dye (Life Technologies) $(10 \mu \mathrm{g} / \mathrm{mL})$ for $1 \mathrm{~h}$. Cells were then washed two times with $100 \mu \mathrm{L}$ PBS and one time with $100 \mu \mathrm{L}$ of RPMI containing $10 \%$ FBS before infection. Cells were incubated with $P$. aeruginosa $\mathrm{CHA}$ or the $\triangle p s c E$ mutant $(\mathrm{MOI}=10)$ in presence of compounds diluted at three concentrations (30 $\mu \mathrm{M}, 10 \mu \mathrm{M}, 3 \mu \mathrm{M})$. Microscopy and imaging were performed using the same protocol as described above, except that the objective was set to $10 \mathrm{X}$, the acquisition time of RED channel was used for Dii staining detection and the image acquisition was performed every $15 \mathrm{~min}$ for $4 \mathrm{~h}$. For analysis, the Red Object Confluence (Percent) in RED channel was measured to quantify the cell area by applying a threshold of 0.3 and a radius of $50 \mu \mathrm{m}$. Data were used to calculate the percentage of cell shrinkage at each time point in comparison to the total cells area at the starting point.

For Yersinia enterocolitica infection experiment, HeLa cells and Cells tracker green (CTg) ((Life Technologies) dye were used. The same protocol as described above was used for CTg staining detection.

Bright nuclei. A549 cells were cultured overnight at 12,500 cells $/ 100 \mu \mathrm{L} /$ well in Black $\mu$ clear 96-well plates (Greiner) in RPMI supplemented with $10 \%$ of FBS at $37{ }^{\circ} \mathrm{C}$. Two hours before infection, medium was replaced with $100 \mu \mathrm{L}$ of fresh RPMI containing $10 \%$ FBS and Hoechst Vital (Sigma Aldrich) at $1 \mu \mathrm{g} / \mathrm{mL}$ to label cell nuclei. After one hour of incubation, cells were washed two times with $100 \mu \mathrm{L}$ of medium and then incubated with $P$. aeruginosa $\mathrm{CHA}$ or the $\triangle p s c F$ mutant $(\mathrm{MOI}=10)$ in presence of compounds. The image acquisitions were performed using the automated microscope ArrayScan VTI (Thermo Scientific) as previously described. ${ }^{36}$ In brief, four images per well were acquired with the $5 \mathrm{X}$ objective every $15 \mathrm{~min}$ for 4 h. Analyses were performed by measuring the nucleus fluorescence intensity using HCS Studio v6.5.0 software and the bright nuclei reflecting stressed cells were discriminated by applying a threshold of 1,200 fluorescence arbitrary units (a.u).

Analysis of ExoS-Bla secretion. $P$. aeruginosa $\mathrm{CHA} \triangle e x o S / E x o S$-Bla and CHA $\Delta p s c F /$ ExoS-Bla were grown overnight in LB containing Carbenicillin (300 $\mu \mathrm{g} / \mathrm{mL})$. Culture were then diluted in LB containing EGTA $(5 \mathrm{mM})$ and $\mathrm{MgCl}_{2}(20 \mathrm{mM})$, and distributed $(90$ $\mu \mathrm{L}$ per well) in a 96-well plate (Greiner 353072) in presence of compounds diluted at three concentrations $(30 \mu \mathrm{M}, 10 \mu \mathrm{M}, 3 \mu \mathrm{M})$. The bacterial final OD was 0.001 and plates were put into an incubator at $37^{\circ} \mathrm{C}$ with shaking of $300 \mathrm{rpm}$. After $3 \mathrm{~h}$ of culture, $9 \mu \mathrm{L}$ of Nitrocefin (Calbiochem) pre-diluted in PBS (250 $\mu \mathrm{g} / \mathrm{mL}$ ) were added and the OD $490_{\mathrm{nm}}$ was measured after $15 \mathrm{~min}$ of incubation at $37^{\circ} \mathrm{C}$ to $\operatorname{detect} \beta$ - 
lactamase activity. To control the absence of direct effect of compounds on $\beta$-lactamase activity, bacteria were cultured in $3 \mathrm{~mL}$ of LB containing EGTA and $\mathrm{MgCl}_{2}$ at $\mathrm{OD}$ of 0.1 for $3 \mathrm{~h}$ at $300 \mathrm{rpm}$ and $37^{\circ} \mathrm{C} .500$ $\mu \mathrm{L}$ of bacteria culture were then centrifuged at 11,000 $\mathrm{g}$ for $5 \mathrm{~min}$ and the supernatant containing ExoS-Bla was diluted 50 times in $\mathrm{LB} \mathrm{Mg}^{2+}$ EGTA. The diluted supernatant was distributed in a 96-well plate (Greiner 353072) containing compounds and the $\beta$-lactamase activity was detected by adding Nitrocefin as described above. Determination of $\mathrm{IC}_{50}$ for ExoS-Bla secretion in the presence of $12(6,4)$ or $12(4,6)$ was performed as described above excepting the following modifications. Compounds concentrations ranged from 50 to $1.6 \mu \mathrm{M}$ in two-fold serial dilutions. Bacteria were inoculated at OD 0.01 and centrifuged at the end of the incubation. Nitrocefin hydrolysis was monitored on $60 \mu \mathrm{L}$ of supernatant every minute and slopes were used to quantify ExoS-Bla. Absorbance values were measured on a SAFAS Microplate Readers MP96.

\section{Bacterial motility and biofilm formation}

$P$. aeruginosa CHA swimming motility was performed by inoculating bacteria on top of LB agar made with $10 \mathrm{~g} / \mathrm{l}$ tryptone, $0.3 \%$ agarose and $5 \mathrm{~g} / \mathrm{L}$ $\mathrm{NaCl}$. Petri dishes were incubated at $37{ }^{\circ} \mathrm{C}$ for $6 \mathrm{~h}$ and the diameters of the swimming rings were measured for three independent biological replicates.

$P$. aeruginosa CHA twitching motility was performed by inoculating bacteria at the interface between the plastic petri dish and LB agar made with10 $\mathrm{g} / \mathrm{L}$ tryptone, $5 \mathrm{~g} / \mathrm{L}$ yeast extract, $1 \%$ agarose and 10 $\mathrm{g} / \mathrm{L} \mathrm{NaCl}$. Petri dishes were incubated at $37{ }^{\circ} \mathrm{C}$ for $32 \mathrm{~h}$ and agar was removed. The zone of twitching was then revealed by Coomassie blue staining and the twitching ring diameters were measured for three independent biological replicates.

Biofilm formation was assessed by inoculating $1 \mathrm{~mL}$ of LB at OD 0.2 in a polystyrene 24 -well plate with overnight cultures. The plate was incubated for 24 hours at $29^{\circ} \mathrm{C}$ without agitation and the air-liquid biofilm stained with $25 \mu \mathrm{L}$ of a $0.1 \%$ solution of crystal violet. After two washes with water, the stained biofilm was dissolved in $30 \%$ acetic acid and quantified in a multi-plate reader at $595 \mathrm{~nm}$.

Bacterial intracellular ATP measurement. $P$. aeruginosa CHA overnight cultures were grown in $3 \mathrm{~mL}$ of LB in presence or absence of $\mathbf{1 2}(\mathbf{6 , 4 )}$ and 12(4,6) until $\mathrm{DO}_{600}$ of 1 . Bacterial cultures were centrifuged and bacterial pellets were resuspended in Tris-EDTA solution. The bacterial suspensions were then heated at $100{ }^{\circ} \mathrm{C}$ for $5 \mathrm{~min}$ and the ATP content was dosed using the Kit luminescence following the manufacturer instructions (Invitrogen: A22066). Statistical analyses were performed using R (version 3.4.4) for the comparison of multiple groups by oneway ANOVA.

Western blot analysis of ExoS, ExoT and PopD secretion. $P$. aeruginosa CHA was grown overnight in LB containing and cultures were then diluted in $3 \mathrm{~mL}$ of fresh LB containing EGTA $(5 \mathrm{mM}), \mathrm{MgCl}_{2}(20 \mathrm{mM})$ and $12(6,4)$ or $12(4,6)$ at three concentration $(30 \mu \mathrm{M}$, $12.5 \mu \mathrm{M}, 5 \mu \mathrm{M})$. Bacteria were incubated at $37^{\circ} \mathrm{C}$ under shaking for $2.5 \mathrm{~h}$ and $1 \mathrm{~mL}$ of bacterial culture was centrifuged at 11,000 rpm for $3 \mathrm{~min}$. Supernatant and pellet fractions were then analyzed by western blot with anti-Exoenzyme $S$ and anti-PopD antibodies.

Galleria mellonella infection. Calibrated larvae (reference \#101040) were purchased from Sudestappats (Queige, France) and used on the day of receipt. Overnight cultures of $P$. aeruginosa CHA WT and $\triangle p s c E$ were grown in $\mathrm{LB}$ until $\mathrm{OD}_{600}$ of 1 . Bacterial culture were then centrifuged and the pellet were washed three time with sterile PBS. Afterward, the bacterial pellet were diluted in PBS to obtain a calculated dose of 5 bacteria $/ \mu \mathrm{L}$. The larvae were injected with $10 \mu \mathrm{L}$ of bacteria solution (50 bacteria) near the penultimate, or last pro-legs. Another group was injected with $10 \mu \mathrm{L}$ PBS only as a control. One hour after bacteria injection, $12(6,4)$ or $\mathbf{1 2}(4,6)$ were injected at a final concentration of $12.5 \mu \mathrm{M}$ in the infected larvae. The larvae masses slightly varied around $250 \mathrm{mg}$ and were used to calculate treatment doses $(250 \mathrm{mg}$ equal to $250 \mathrm{~mL}$ ). The infected larvae were then placed in a $100 \mathrm{~mm}$ Petri dish lined with paper towel (10 larvae per dish) and incubated at $37{ }^{\circ} \mathrm{C}$ for $20 \mathrm{~h}$. After 12 to $13 \mathrm{~h}$, infected larvae were monitored every 30 min to enumerate deaths. Data from four independent experiments using groups of 10 larvae were pooled to obtain $n=40$. The survival data were plotted using Kapan-Meier estimation. The statistical comparison was performed using the log-rank test and false discovery rate (FDR) correction was applied.

\section{- ASSOCIATED CONTENT}

Supporting Information

ELISA results

Molecular modelling/docking

Effect on other Gram-negative bacteria

Long-term toxicity on HepG2 cells

Synthesis

Supporting information references

${ }^{1} \mathrm{H}$ and ${ }^{13} \mathrm{C}$ NMR spectra

\section{- AUTHOR INFORMATION}

Corresponding authors

*eric.faudry@cea.fr

*yung-sing.wong@univ-grenoble-alpes.fr

Notes

The authors declare no competing financial interest.

\section{- ACKNOWLEDGEMENT}

The authors, TDN, SP, CB, YB, MOF, IA and EF received funding from the associations "Vaincre la mucoviscidose" and "Gregory Lemarchand", grants from the AVIESAN T3SS (ANR PRP1.4), the Laboratory of Excellence GRAL (ANR-10-LABX- 
49-01), the Agence Nationale de Recherche (ANR15-CE11-0018-01). The authors YB, AT, AF and YSW received funding from the Labex ARCANE and CBH-EUR-GS (ANR-17-EURE-0003). Part of this work has been performed at the CMBA screening platform which is a member of GIS-IBiSA and ChemBioFrance infrastructure and is supported by GRAL, financed within the University Grenoble Alpes graduate school (Ecoles Universitaires de Recherche) CBH-EUR-GS (ANR-17-EURE-0003). The molecular dynamics computations were performed using the Froggy platform of the CIMENT infrastructure (https://ciment.ujfgrenoble.fr), which is supported by the Rhône-Alpes region (GRANT CPER07_13 CIRA), the OSUG@2020 labex (reference ANR10 LABX56) and the Equip@Meso project (reference ANR-10EQPX-29-01) of the Programme Investissements d'Avenir supervised by the Agence Nationale pour la Recherche. Authors are grateful to Emmanuelle Soleilhac and Peter Panchev for inspired discussion and acknowledge Laura Monlezun for the initial drawing of the T3SS schematic representation. The authors also acknowledge the staff of the Institut Chimique Moléculaire de Grenoble (ICMG) analytical platform.

\section{- REFERENCES}

(1) Tacconelli, E.; Carrara, E.; Savoldi, A.; Harbarth, S.; Mendelson, M.; Monnet, D. L.; Pulcini, C.; Kahlmeter, G.; Kluytmans, J.; Carmeli, Y.; Ouellette, M.; Outterson, K.; Patel, J.; Cavaleri, M.; Cox, E. M.; Houchens, C. R.; Grayson, M. L.; Hansen, P.; Singh, N.; Theuretzbacher, U.; Magrini, N.; Aboderin, A. O.; Al-Abri, S. S.; Awang Jalil, N.; Benzonana, N.; Bhattacharya, S.; Brink, A. J.; Burkert, F. R.; Cars, O.; Cornaglia, G.; Dyar, O. J.; Friedrich, A. W.; Gales, A. C.; Gandra, S.; Giske, C. G.; Goff, D. A.; Goossens, H.; Gottlieb, T.; Guzman Blanco, M.; Hryniewicz, W.; Kattula, D.; Jinks, T.; Kanj, S. S.; Kerr, L.; Kieny, M.-P.; Kim, Y. S.; Kozlov, R. S.; Labarca, J.; Laxminarayan, R.; Leder, K.; Leibovici, L.; Levy-Hara, G.; Littman, J.; Malhotra-Kumar, S.; Manchanda, V.; Moja, L.; Ndoye, B.; Pan, A.; Paterson, D. L.; Paul, M.; Qiu, H.; Ramon-Pardo, P.; Rodríguez-Baño, J.; Sanguinetti, M.; Sengupta, S.; Sharland, M.; SiMehand, M.; Silver, L. L.; Song, W.; Steinbakk, M.; Thomsen, J.; Thwaites, G. E.; van der Meer, J. W.; Van Kinh, N.; Vega, S.; Villegas, M. V.; WechslerFördös, A.; Wertheim, H. F. L.; Wesangula, E.; Woodford, N.; Yilmaz, F. O.; Zorzet, A. Discovery, Research, and Development of New Antibiotics: The WHO Priority List of Antibiotic-Resistant Bacteria and Tuberculosis. Lancet Infect. Dis. 2018, 18 (3), 318-327. DOI 10.1016/S1473-3099(17)30753-3.

(2) Kalanuria, A.; Zai, W.; Mirski, M. VentilatorAssociated Pneumonia in the ICU. Crit. Care 2014, 18 (2), 208. DOI 10.1186/cc13775.

(3) Patel, B. M.; Paratz, J. D.; Mallet, A.; Lipman, J.; Rudd, M.; Muller, M. J.; Paterson, D. L.; Roberts, J. A. Characteristics of Bloodstream Infections in Burn Patients: An 11-Year Retrospective Study. Burns 2012, $38 \quad$ (5), 685-690. DOI 10.1016/j.burns.2011.12.018.
(4) Murray, T. S.; Egan, M.; Kazmierczak, B. I. Pseudomonas Aeruginosa Chronic Colonization in Cystic Fibrosis Patients: Curr. Opin. Pediatr. 2007, $19 \quad$ (1), 83-88. DOI 10.1097/MOP.0b013e3280123a5d.

(5) Burrows, L. L. The Therapeutic Pipeline for Pseudomonas Aeruginosa Infections. ACS Infect. Dis. 2018, 4 (7), 1041-1047. DOI 10.1021/acsinfecdis. 8 b00112.

(6) Wagner, S.; Sommer, R.; Hinsberger, S.; Lu, C.; Hartmann, R. W.; Empting, M.; Titz, A. Novel Strategies for the Treatment of Pseudomonas Aeruginosa Infections. J. Med. Chem. 2016, 59 (13), 5929-5969. DOI 10.1021/acs.jmedchem.5b01698.

(7) Dickey, S. W.; Cheung, G. Y. C.; Otto, M. Different Drugs for Bad Bugs: Antivirulence Strategies in the Age of Antibiotic Resistance. Nat. Rev. Drug Discov. 2017, $16 \quad$ (7), 457-471. DOI 10.1038/nrd.2017.23.

(8) Johnson, B. K.; Abramovitch, R. B. Small Molecules That Sabotage Bacterial Virulence. Trends Pharmacol. Sci. 2017, 38 (4), 339-362. DOI 10.1016/j.tips.2017.01.004.

(9) Deng, W.; Marshall, N. C.; Rowland, J. L.; McCoy, J. M.; Worrall, L. J.; Santos, A. S.; Strynadka, N. C. J.; Finlay, B. B. Assembly, Structure, Function and Regulation of Type III Secretion Systems. Nat. Rev. Microbiol. 2017, 15 (6), 323-337. DOI 10.1038/nrmicro.2017.20

(10) Warrener, P.; Varkey, R.; Bonnell, J. C.; DiGiandomenico, A.; Camara, M.; Cook, K.; Peng, L.; Zha, J.; Chowdury, P.; Sellman, B.; Stover, C. K. A Novel Anti-PcrV Antibody Providing Enhanced Protection against Pseudomonas Aeruginosa in Multiple Animal Infection Models. Antimicrob. Agents Chemother. 2014, 58 (8), 4384-4391. DOI 10.1128/AAC.02643-14.

(11) Anantharajah, A.; Mingeot-Leclercq, M.-P.; Van Bambeke, F. Targeting the Type Three Secretion System in Pseudomonas Aeruginosa. Trends Pharmacol. Sci. 2016, 37 (9), 734-749. DOI 10.1016/j.tips.2016.05.011

(12) Charro, N.; Mota, L. J. Approaches Targeting the Type III Secretion System to Treat or Prevent Bacterial Infections. Expert Opin. Drug Discov. 2015, $\quad 10 \quad$ (4), 373-387. $\quad$ DOI 10.1517/17460441.2015.1019860.

(13) Duncan, M. C.; Linington, R. G.; Auerbuch, V. Chemical Inhibitors of the Type Three Secretion System: Disarming Bacterial Pathogens. Antimicrob. Agents Chemother. 2012, 56 (11), 5433-5441. DOI 10.1128/AAC.00975-12.

(14) Gu, L.; Zhou, S.; Zhu, L.; Liang, C.; Chen, X. SmallMolecule Inhibitors of the Type III Secretion System. Molecules 2015, 20 (9), 17659-17674. DOI 10.3390/molecules200917659.

(15) Kline, T.; B. Felise, H.; Sanowar, S.; I. Miller, S. The Type III Secretion System as a Source of Novel Antibacterial Drug Targets. Curr. Drug Targets 2012, 13 (3), 338-351. DOI 10.2174/138945012799424642.

(16) Tsou, L. K.; Dossa, P. D.; Hang, H. C. Small Molecules Aimed at Type III Secretion Systems to Inhibit Bacterial Virulence. Med Chem Commun 2013, 4 (1), 68-79. DOI 10.1039/C2MD20213A.

(17) Feng, C.; Huang, Y.; He, W.; Cheng, X.; Liu, H.; Huang, Y.; Ma, B.; Zhang, W.; Liao, C.; Wu, W.; Shao, Y.; Xu, D.; Su, Z.; Lu, W. Tanshinones: Firstin-Class Inhibitors of the Biogenesis of the Type 3 Secretion System Needle of Pseudomonas 
aeruginosa for Antibiotic Therapy. ACS Cent. Sci. 2019, 5 (7), 1278-1288. DOI 10.1021/acscentsci.9b00452.

(18) Quinaud, M.; Chabert, J.; Faudry, E.; Neumann, E.; Lemaire, D.; Pastor, A.; Elsen, S.; Dessen, A.; Attree, I. The PscE-PscF-PscG Complex Controls Type III Secretion Needle Biogenesis in Pseudomonas Aeruginosa. J. Biol. Chem. 2005, 280 (43), 36293-36300. DOI 10.1074/jbc.M508089200.

(19) Quinaud, M.; Plé, S.; Job, V.; Contreras-Martel, C.; Simorre, J.-P.; Attree, I.; Dessen, A. Structure of the Heterotrimeric Complex That Regulates Type III Secretion Needle Formation. Proc. Natl. Acad. Sci. U. S. A. 2007, 104 (19), 7803-7808. DOI 10.1073/pnas.0610098104.

(20) Ple, S.; Job, V.; Dessen, A.; Attree, I. Cochaperone Interactions in Export of the Type III Needle Component PscF of Pseudomonas Aeruginosa. J. Bacteriol. 2010, 192 (14), 3801-3808. DOI 10.1128/JB.00117-10.

(21) Modell, A. E.; Blosser, S. L.; Arora, P. S. Systematic Targeting of Protein-Protein Interactions. Trends Pharmacol. Sci. 2016, 37 (8), 702-713. DOI 10.1016/j.tips.2016.05.008.

(22) Scott, D. E.; Bayly, A. R.; Abell, C.; Skidmore, J. Small Molecules, Big Targets: Drug Discovery Faces the Protein-protein Interaction Challenge. Nat. Rev. Drug Discov. 2016, 15 (8), 533-550. DOI 10.1038/nrd.2016.29.

(23) Milhas, S.; Raux, B.; Betzi, S.; Derviaux, C.; Roche, P.; Restouin, A.; Basse, M.-J.; Rebuffet, E.; Lugari, A.; Badol, M.; Kashyap, R.; Lissitzky, J.-C.; Eydoux, C.; Hamon, V.; Gourdel, M.-E.; Combes, S.; Zimmermann, P.; Aurrand-Lions, M.; Roux, T.; Rogers, C.; Müller, S.; Knapp, S.; Trinquet, E.; Collette, Y.; Guillemot, J.-C.; Morelli, X. ProteinProtein Interaction Inhibition (2P2I)-Oriented Chemical Library Accelerates Hit Discovery. ACS Chem. Biol. 2016, 11 (8), 2140-2148. DOI 10.1021/acschembio.6b00286.

(24) Smith, M. C.; Gestwicki, J. E. Features of Proteinprotein Interactions That Translate into Potent Inhibitors: Topology, Surface Area and Affinity. Expert Rev. Mol. Med. 2012, 14 . DOI 10.1017/erm.2012.10.

(25) Sable, R.; Jois, S. Surfing the Protein-Protein Interaction Surface Using Docking Methods: Application to the Design of PPI Inhibitors. Molecules 2015, 20 (6), 11569-11603. DOI 10.3390/molecules200611569.

(26) Shin, W.-H.; Christoffer, C. W.; Kihara, D. In Silico Structure-Based Approaches to Discover ProteinProtein Interaction-Targeting Drugs. Methods 2017, 131, 22-32. DOI 10.1016/j.ymeth.2017.08.006.

(27) Zhang, J.-H.; Chung, T. D. Y.; Oldenburg, K. R. A Simple Statistical Parameter for Use in Evaluation and Validation of High Throughput Screening Assays. J. Biomol. Screen. 1999, 4 (2), 67-73. DOI 10.1177/108705719900400206.

(28) Anantharajah, A.; Buyck, J. M.; Sundin, C.; Tulkens, P. M.; Mingeot-Leclercq, M.-P.; Van Bambeke, F. Salicylidene Acylhydrazides and Hydroxyquinolines Act as Inhibitors of Type Three Secretion Systems in Pseudomonas Aeruginosa by Distinct Mechanisms. Antimicrob. Agents Chemother. 2017, 61 (6). DOI 10.1128/AAC.0256616.

(29) Volk, C. A.; Köck, M. Viscosaline: New 3-Alkyl Pyridinium Alkaloid from the Arctic Sponge
Haliclona Viscosa. Org. Biomol. Chem. 2004, 2 (13), 1827-1830. DOI 10.1039/b403413a.

(30) Gil, L.; Gateau-Olesker, A.; Wong, Y.-S.; Chernatova, L.; Marazano, C.; Das, B. C. Synthesis of Macrocyclic or Linear Pyridinium Oligomers from 3-Substituted Pyridines. Model Synthetic Studies toward Macrocyclic Marine Alkaloids. Tetrahedron Lett. 1995, 36 (12), 2059-2062. DOI 10.1016/0040-4039(95)00181-B.

(31) Kaiser, A.; Billot, X.; Gateau-Olesker, A.; Marazano, C.; Das, B. C. Selective Entry to the Dimeric or Oligomeric Pyridinium Sponge Macrocycles via Aminopentadienal Derivatives. Possible Biogenetic Relevance with Manzamine Alkaloids. J. Am. Chem. Soc. 1998, 120 (32), 80268034. DOI 10.1021/ja9805369.

(32) Cironi, P.; Tulla-Puche, J.; Barany, G.; Albericio, F.; Alvarez, M. Solid-Phase Syntheses of Furopyridine and Furoquinoline Systems. Org. Lett. 2004, 6 (9), 1405-1408. DOI 10.1021/ol049762f.

(33) Fletcher, J. T.; Bumgarner, B. J.; Engels, N. D.; Skoglund, D. A. Multidentate 1,2,3-TriazoleContaining Chelators from Tandem Deprotection/Click Reactions of (Trimethylsilyl)Alkynes and Comparison of Their Ruthenium(II) Complexes. Organometallics 2008, 27 (21), 5430-5433. DOI 10.1021/om800768k.

(34) SiteMap, SiteMap version 3.6.; Schrödinger, LLC: New York, NY, 2015.

(35) Hauser, A. R. The Type III Secretion System of Pseudomonas Aeruginosa: Infection by Injection. Nat. Rev. Microbiol. 2009, 7 (9), 654-665. DOI 10.1038/nrmicro2199.

(36) Wallez, Y.; Bouillot, S.; Soleilhac, E.; Huber, P.; Attrée, I.; Faudry, E. CLIQ-BID: A Method to Quantify Bacteria-Induced Damage to Eukaryotic Cells by Automated Live-Imaging of Bright Nuclei. Sci. Rep. 2018, 8 (1). DOI 10.1038/s41598-01718501-9.

(37) Diepold, A.; Armitage, J. P. Type III Secretion Systems: The Bacterial Flagellum and the Injectisome. Philos. Trans. R. Soc. B Biol. Sci. 2015, 370 (1679), $20150020 . \quad$ DOI 10.1098/rstb.2015.0020.

(38) Mattick, J. S. Type IV Pili and Twitching Motility. Annu. Rev. Microbiol. 2002, 56 (1), 289-314. DOI 10.1146/annurev.micro.56.012302.160938.

(39) Sall, K. M.; Casabona, M. G.; Bordi, C.; Huber, P.; de Bentzmann, S.; Attrée, I.; Elsen, S. A GacS Deletion in Pseudomonas Aeruginosa Cystic Fibrosis Isolate CHA Shapes Its Virulence. PLoS ONE 2014, 9 (4), e95936. DOI 10.1371/journal.pone.0095936.

(40) Jander, G.; Rahme, L. G.; Ausubel, F. M. Positive Correlation between Virulence of Pseudomonas Aeruginosa Mutants in Mice and Insects. $J$. Bacteriol. 2000, 182 (13), 3843-3845. DOI 10.1128/JB.182.13.3843-3845.2000.

(41) Tsai, C. J.-Y.; Loh, J. M. S.; Proft, T. Galleria Mellonella Infection Models for the Study of Bacterial Diseases and for Antimicrobial Drug Testing. Virulence 2016, 7 (3), 214-229. DOI 10.1080/21505594.2015.1135289.

(42) Verove, J.; Bernarde, C.; Bohn, Y.-S. T.; Boulay, F.; Rabiet, M.-J.; Attree, I.; Cretin, F. Injection of Pseudomonas Aeruginosa Exo Toxins into Host Cells Can Be Modulated by Host Factors at the Level of Translocon Assembly and/or Activity. PLoS ONE 2012, 7 (1), e30488. DOI 10.1371/journal.pone.0030488. 
Graphic entry for the Table of Contents

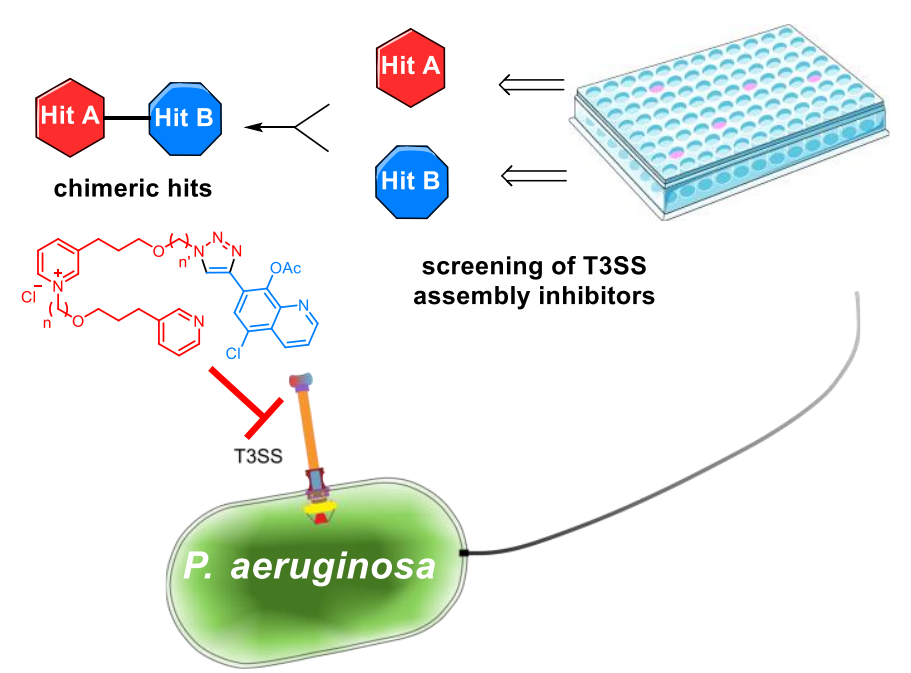

